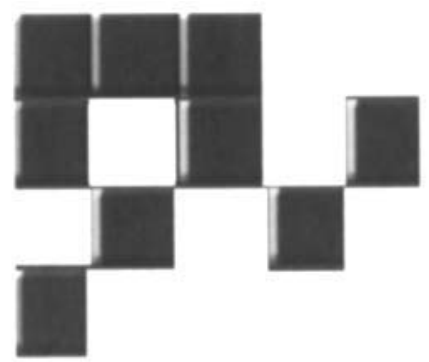

SECTION II

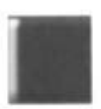

\title{
Knowledge Discovery
}




\title{
Organizational Knowledge and Communities of Practice
}

\author{
Elisabeth Davenport \\ Hazel Hall \\ Napier University, Edinburgh
}

\section{Introduction}

A community of practice has recently been defined as "a flexible group of professionals, informally bound by common interests, who interact through interdependent tasks guided by a common purpose thereby embodying a store of common knowledge" (Jubert, 1999, p. 166). The association of communities of practice with the production of collective knowledge has long been recognized, and they have been objects of study for a number of decades in the context of professional communication, particularly communication in science (Abbott, 1988; Bazerman \& Paradis, 1991). Recently, however, they have been invoked in the domain of organization studies as sites where people learn and share insights. If, as Stinchcombe suggests, an organization is "a set of stable social relations, deliberately created, with the explicit intention of continuously accomplishing some specific goals or purposes" (Stinchcombe, 1965, p. 142), where does this "flexible" and "embodied" source of knowledge fit? Can communities of practice be harnessed, engineered, and managed like other organizational groups, or does their strength lie in the fact that they operate outside the stable and persistent social relations that characterize the organization? 
The current "state of the notion" reveals a number of tensions. Brown and Duguid (1993, p. 187) point out that "the community of practice is by no means necessarily harmonious, nor is it necessarily a face-to-face or contiguous grouping." The community of practice, as we understand it, denotes the level of the social world at which a particular practice is common and coordinated, at which generic understandings are created and shared, and negotiation is conducted. This is the locus at which it is possible to explore the social and physical context in which artifacts are used, to understand the roles objects play internally and across boundaries. If, as Bowker and Star (1999) suggest, the concepts that drive institutions are political products, we should not be surprised to find that communities of practice are described, defined, and justified in a number of different ways. For epistemologists, communities of practice are a means of exploring concepts of social or collective knowledge. For managers interested in performance, they offer an opportunity to derive templates or frameworks for the creation of organizational knowledge at a number of levels (the workgroup, the firm, the sector) in the interest of improved productivity. For designers, they provide case studies of interactions with artifacts and infrastructures in a range of off-line and online contexts.

Our review of the literature takes account of these different approaches in covering a number of topics: contributing domains; current (corporate) manifestations; motivations and infrastructures; tools for analyzing communities of practice; and analytic case studies.

\section{Contributing Domains}

We have identified three domains that contribute to current concepts of communities of practice. The first is studies of situated learning (and situated action). The second is studies of distributed cognition (or the interplay of people, artifacts, and context in problem solving at different levels). The third is communication studies, specifically a linguistic tradition that explores social networks by means of discourse analysis and conversation analysis (see, for example, Cohen \& Sproull, 1996; Engeström \& Middleton, 1997). In each of these domains, knowledge can be described as "corporate," that is, embodied in the work of the collective 
and expressed (implicitly or explicitly) in the interactions of participants who share tasks.

\section{Situated Learning and Situated Action}

We start our review of origins with "situated learning," as it provides examples of "primitives." By "primitives" we mean examples of practice in physical communities: midwives, butchers, flutemakers. We would contrast these with "complexes," that is, examples of practice in virtual worlds. Seminal texts by Lave $(1988,1991)$ and Lave and Wenger (1991) demonstrate that learning is grounded in context and artifacts, and that context, in most situations, is a community in which participants must learn how to handle the tasks and artifacts that are handed to them. This is achieved gradually, as a novice moves from a condition of peripheral participation to full membership. Educationists trying to model the classroom process (where learner and pedagogue seek to establish comparable understandings of each one's expectations of the other) have drawn heavily on Lave and Wenger's work. Fleming, for example, states that situated learning draws on the "ordinary, everyday, finely detailed methodic practices of participants to an activity in specific settings" (Fleming, 1994, p. 525). Learning, in this context, means being able to participate appropriately in the settings "where the subject or discipline is being done" (Fleming, 1994, p. 526). Fleming suggests that situated learning can be engineered by deconstructing the process through a number of analytic steps. The first is to identify how sequences of activities are assembled and constructed in the specific settings in which they are used ("structural anatomy"). The next step is to try to understand how methodic practices are used on a given occasion ("functional anatomy"). This step is followed by an exploration of how the "machinery" supports these activities and practices; by asking how descriptions, facts, and processes work together to produce what participants in the learning dialogue recognize as an explanation of the phenomenon in question. Gherardi, Nicolini, and Odella (1998) describe a "situated curriculum" for organizational learning based on Lave's work, taking construction site managers as a case in point.

Lave's work is cited as a major source of inspiration by Brown and Duguid (2000). In 1991, they themselves suggested that a "communities 
of practice" framework could account for organizational learning (Brown \& Duguid, 1991). A number of micro-level empirical studies at Xerox PARC have demonstrated the importance of communities of practice as a locus of problem solving in ad hoc unforeseen contingencies where micro-level adaptations may lead to design modifications in company products. Chaiklin and Lave (1993, p. 14) describe this as "the skilled improvisations, organized in orderly ways, that are designed to maintain openness to the possibilities that the materials at hand present." The photocopier is the specific object of attention in seminal case studies of Xerox engineers (Orr, 1987, 1990) and office workers (Suchman, 1986). A number of different social interactions (dialogues and narrative exchange) that validate innovation at different levels of organization are brought into play in these scenarios, which are repeated at different levels of organization. Situated action has provided a useful theoretical framework for analyzing innovative micro-level responses to organizational blockages and breakdowns in other contexts, such as students offering each other peer assistance in libraries (Twidale \& Nichols, 1996) or insurance firm help-desk operators handling novel procedural requests (Ackerman \& Halverson, 1999). Typically such work is invisible. It is the "articulation" work that gets things done at the local level and allows managers to perceive the contours of the workplace as smoother than they are when examined in detail. There has been much discussion in the "organizational memory" literature of how such local innovations pervade the organization and how their authors achieve recognition (Gerson \& Star, 1986, p. 258).

Brown and Duguid (1998, 2000) draw on Nonaka and Takeuchi's (1995) account (the SECI [Socialization, Externalization, Combination, and Internalization] model) of the interplay of tacit and explicit knowledge in communities of practice. Nonaka and Takeuchi use the term "ba" to describe a multivalent space, where social and individual, tacit and explicit knowledge contribute to emergent innovation. This model of knowledge creation draws its strength from the many parables and case studies (Nonaka 1991; Nonaka \& Konno, 1998; Nonaka, Umemoto \& Sasaki, 1998; von Krogh, Ichijo \& Nonaka, 2000) that show how the concept of "ba" can guide and explain innovation. 


\section{Distributed Cognition}

Lave's 1991 chapter "Situating learning in communities of practice" appeared in an edited volume by Resnick, Levine, and Teasley (1991), which brought together a number of strands of enquiry relevant to communities of practice. The same volume contains a paper by Hutchins, where he takes "tentative steps towards a framework for thinking about cognitive phenomena at the level of groups" (Hutchins, 1991, p. 305) by offering a formal model of "confirmation bias," the propensity to discount evidence that runs counter to an already formed interpretation. In several exemplary studies (e.g., Hutchins 1995a, 1995b, 1996; Hutchins \& Klausen, 1997) of small close operating environments (a bridge of a ship; a cockpit), he presents both a methodology for and an explanation of distributed cognition, or the division of knowledge across people and artifacts as communal tasks are completed in an environment that is more or less familiar. Weick and Roberts (1993) offer a comparable account of flight deck "heedful interrelating." Similar observations can be found in the literature on cockpit resource management (e.g., Ginnett, 1993). Recent work in this area has been undertaken in the interests of designers. Wright, Pocock, and Fields (1988) have explored the information that pilots share when changing shifts and its implication for the design of automated cockpits. A number of studies have explored the use of paper strips in flight control rooms (e.g., Mackay, 1999) again in the context of proposed automation of the tasks that characterize this specialist community. In each of these cases, each member of the team understands an artifact in the light of the activities of those around him or her. Knowledge of how to proceed is cumulative: Each activity is validated by that which follows. Weick $(1995,1996)$ offers a rich account of how this happens in his account of the "substance" of organizational sense making.

Greenberg and Dickelman (2000, p. 18) offer an analytic review of studies of distributed cognition as a "foundation for performance support." Their interest is in "environments that enable people to complete work with a minimum of training or learning in advance of doing a task." They draw heavily on the work of Salomon (1993a, p. 19) to support their claim that "supporting performance on the job in a computermediated environment" fosters knowledge acquisition and "turns 
knowledge into action" more effectively than training in advance. They advocate a focus on activity analysis, with due attention paid to transformations in representation as tasks and outcomes migrate across different levels (Nardi, 1996). They cite Nardi's "person with tool" as an important unit of analysis. A specific example of distributed cognition in a community of practice is provided by Yanow and Cook (Cook \& Yanow, 1993; Yanow, 2000), who describe the construction of flutes by a group of craftsmen. The artifact (the flute) emerges from a sequence of activities performed by specialist artisans, each of whom contributes unique expertise, which is only valuable as part of the collective process of construction. Each contribution is validated by the feel of the product as it passes from hand to hand. Cumulating knowledge is embedded in the product, which embodies the knowledge of the group. A more complicated community is discussed by Perry (1998), who has analyzed a group of civil engineers on a construction site using distributed cognition as an explanatory framework.

\section{Discourse Analysis and Conversation Analysis}

In each of these cases, knowledge emerges in a space where those involved - the interactors - are physically present, where tangible artifacts and human actors intersect, and where tacit knowledge is manifest in action. What about more complicated cases where there are multiple media in play (physical artifacts, documents that support their development, visual and audio recordings that mediate interaction) or where members of a community are dispersed? These are, of course, the conditions that characterize many professional communities, which may be distinguished from other communities of practice by their reliance on explicit knowledge as well as tacit knowledge: a corpus of cumulated experience which becomes, in itself, a key artifact in community activity (Kaufer \& Carley, 1993). A comprehensive and carefully structured corpus is a useful scaffold for situated learners. In many cases, however, domain documentation cumulates in an ad hoc fashion, and finding one's way becomes an important component of apprenticeship. The paths that are used will reflect the practice of the domain community, as much as 
formal architectures (Bishop, 1999; Covi, 1999; Davenport \& Cronin, 1998; Elliott \& Kling, 1997; Erdelez \& Doty, 1999).

What Covi (1999) calls "material mastery" is an important component of "professional capital," or "habitus," a concept explored by Bourdieu (1990) in his exploration of the "logic of practice." Lave (1988) paraphrases "habitus" as "meaning made body," as Bourdieu is making the claim that "much of the generative basis of practice is inscribed in the person in the form of dispositions" (Lave, 1988 p. 181). In many academic and professional communities, "dispositions" are shaped by texts, and apprenticeship or situated learning can be undertaken to a greater or lesser extent by cumulative insight into how to read the range of materials that support work in a given professional domain (Bazerman \& Paradis, 1991). A number of studies have demonstrated that the making of a graduate involves a number of reading stages (Bhatia, 1994; Swales, 1990). In this way individuals learn how to behave as members of a professional group, and thus sustain and reproduce the knowledge of the collective. Emergent professional communities will struggle to have their codified, or explicit, knowledge accepted. In this context, the case of the nursing profession has been discussed in a number of fora; most fully by Bowker and Star (1999, pp. 229-254). In large collectives where members are remote from each other, matters of whom to trust arise, and different collectives have derived different mechanisms to handle these issues: regulation, audit, peer assessment, and recommender systems. Many of these mechanisms operate by means of established documentary and communicative genres. In the section that follows, we review studies of genres and communities of practice.

\section{Genre Analysis}

Historically, certain genres of documentation have been associated with the recurring activities that characterize communities of practice: process manuals, articles of association, contracts, the inventory, records of property transfers, and daybooks. Although such forms show local diversity, they are recognizable within epistemological trading zones (Berkenkotter, 1995) as performing or enacting similar functions; in other words, they function as codes of conduct. They are not totally fixed, however; as new habits emerge and are endorsed by a community of 
practice, they, in turn, become encoded, and join the repertoire of knowledge of how to behave. Where practice changes (as it does in cases where new technologies are introduced into an organization, which may trigger a community of practice), new genres are likely to emerge as practitioners adapt to new circumstances and establish fresh routines. In such cases, genres articulate tacit knowledge; acting as bridges between uncodified "walk-arounds" and codified knowledge; or in Brown and Duguid's terms (1998), "non-canonical" and "canonical" knowledge (also see Nonaka \& Konno, 1998).

Much of our understanding of genres and their role in communities of practice is due to a body of work by Yates, Orlikowski, and their colleagues over the past decade. A broad definition of genres is offered in their groundbreaking paper (Yates \& Orlikowski, 1992) in which they identify three characteristic elements: a recurrent situation, substance ("social motives ... themes ... topics"), and form (structural features, communication medium, and symbolism). Genres are enacted through rules, which associate appropriate elements of form and substance with certain recurrent situations. To engage with a genre is to "implicitly or explicitly draw on genre rules," and also to "reinforce and sustain the legitimacy of those rules" (Yates \& Orlikowski, 1992, pp. 301-302). Genres exist at different levels of abstraction, and will be defined differently "in different cultures and at different times" (Yates \& Orlikowsi, 1992 , p. 303). What is interesting about genres is their dual status as (1) an articulation of what has emerged as appropriate behavior (their role as a categorizing device), and (2) as a prescription for activity in a community of practice (their role as a regulatory device). Genres are thus, say Yates and Orlikowski, structurational devices.

In subsequent work (Orlikowski \& Yates, 1994; Yates, Orlikowski, \& Rennecker, 1997), they develop the concept of a genre repertoire, which can account for interactive behavior in both off-line and online communities. A genre repertoire is "largely implicit, and rooted in members' prior experiences of working and interacting. Once established, a genre repertoire serves as a powerful social template for shaping how, why, and with what effort members of a community interact to get their work done" (Orlikowski \& Yates, 1994, p. 541). Davenport (1999) draws on this work in micro studies of information and communication technologies in households, and of a small networked enterprise. She presents 
digital genres as instances of self-organizing social coding devices: as new habits emerge and are endorsed by a community of practice, they in turn become encoded, and join the repertoire of knowledge of how to behave (also see Davenport \& Rosenbaum, 2000).

Brown and Duguid (1994) offer a rich review of genres and their role in communities of practice. Genres, they claim, are a fundamental feature of group cognition: People "read" an artifact against or in the context of its "type," and that is how they acquire an understanding of it. The "types" in these readings are "genres." They evolve locally and continually in practice, and are limited to particular organizations or institutions to the extent that "old-timers" can usually recognize organizational newcomers by their generic transgressions. Because genres are coupled with context, they carry many cues about the environment-the equivalent of a portable context. The social or communal context of genres is ignored at the designer's peril. Brown and Duguid cite the persistent failure of attempts to have the public adopt customized electronic newspapers as a case in point; none of these has offered the flexible affordance of the paper version. Because they are flexible and can evolve, genres are a highly appropriate form for the articulation of practice.

Conversational genres play as important a role in community formation as documentary genres, and studies of business genres have focused as much on the former as on the latter. (Bargiela-Chiappini \& Nickerson, 1999; Boden, 1994; Loos, 1999). Genre can be an important component of framing (Tannen, 1995), or the setting up and fulfillment of expectations (in the case of Tannen's study, expectations about the storyline of a movie). Much business communication can be analyzed as a form of conversation, where knowledge of turn-taking, or appropriate response, is important (Goodwin, 1995). Conversation, defined broadly in this way, is a medium for organizational knowledge, as it is inherently collective or heteroglossic (it is not acceptable to talk to oneself), and it generates a social artifact (a contract, for example) that emerges as each participant in the practice takes part. Turn-taking is analogous to the passing of the baton or the sequential handling of an artifact that contributes to a collective outcome. In the case of conversation, this may be a completed transaction, or a negotiated solution to a problem. Learning how to handle conversation is an important part of participation in communities of 
practice, both online and off-line (Schlegoff, 1991). Erickson (1999) provides a pertinent case study of an online community that is learning to compose limericks, and we return to this topic in the section on online communities of practice.

\section{Communities of Practice at Work}

Discussions and case studies of communities of practice in the workplace fall into two classes: those written from a performative perspective and those written from an interpretive or constructivist perspective (Contu \& Wilmott, 2000). The most complete recent account of communities of practice is provided by Wenger (1998, 2000a, 2000b; Wenger \& Snyder, 2000), whose first engagement with the topic was as coauthor of the seminal interpretive text on situated learning (Lave \& Wenger, 1991). Wenger's current work, however, has been criticized for its performative approach:

We encounter an (unacknowledged) shift or slippage from an earlier representation of learning as praxis fashioned within a discourse of critique to a formulation of learning as technology conceived within a discourse of regulation and performance.

(Contu \& Wilmott, 2000, p. 272-273)

Fox (2000) criticizes Wenger's recent account of communities of practice for failure to address adequately issues of power in the workplace. In the section that follows, we review both approaches, starting with the performative perspective.

\section{The Performative Perspective}

Wenger's $(1998$, p. 4) monograph offers a comprehensive account of communities of practice. They are, he suggests, groups whose members are bound by their participation in a "valued enterprise," such as "singing in tune," "discovering scientific facts," or "fixing a machine." To participate competently in such an enterprise is to show knowledge of the area involved, and learning in a community of practice is the evolving ability to have meaningful experiences. An important component of this is community identity, which allows members of the group to share their personal histories and experiences of change. Identity, says 
Wenger, allows communities to reflect on the complex relations that define them and it involves activities like categorization, association, and differentiation (Wenger, 1998, p. 13). The theme of identity is developed at length in a later chapter, "Modes of belonging" (Wenger, 1998, pp. 172-187). Wenger (1998, pp. 58-59) develops his theme in a sustained case study of an insurance claims office, and covers ground similar to that discussed in studies of distributed cognition, using the terms "reification" and "participation" to describe the "interplay" of humans and artifacts.

Communities of practice are distinguished from other groupings by mutual engagement, joint enterprise (that implies a regime of mutual accountability), a shared repertoire (that both articulates shared experience and records its history), and the emergence of meaning in practice. Wenger discusses the artifacts that constitute this repertoire at some length, and acknowledges the importance of genres in this context. $\mathrm{He}$ restricts his use of the term to traditional documentary sources, explaining in an endnote that he begs to differ from those who use the term to describe "anything that is both collective and tacit" (Wenger, 1998, p. 288). Communities of practice are ambivalent as, like any community, they are contained within boundaries, but their boundaries are areas where connections with others may be made. Wenger discusses what happens at the edges of community at length, and we review his comments in the section on infrastructure later in this chapter. He emphasizes that communities of practice are local phenomena, and offers a checklist of features that might allow an observer to say that a particular group was such a community (Wenger, 1998, pp. 122-123). But the "localness" of a community of practice must not result in isolation: "It is incumbent on a learning community to deal with its position in various communities and economies with respect to various enterprises, styles and discourses. It must seek the reconfigurations necessary to make its learning empowering locally and in other relevant contexts" (Wenger, 1998, p. 220).

In a subsequent article, Wenger and Snyder (2000) discuss the significance of the community of practice as an organizational form that is informal, driven by the desire to share expertise, sets its own agenda, finds its own "shape," and is sustained by the interest and passion of participants. Communities of practice are not goal driven (unlike teams 
and projects), nor are they necessarily deadline driven. Freedom from such constraints makes them, in some circumstances, environments that are more hospitable to sharing and synergy than conventional competing organizational subgroups. In the latter, commitment to knowledge sharing may be conditioned by existing institutional incentive schemes that may offer little or no obvious reward to those who are asked to participate in knowledge management initiatives. What communities of practice offer is a chance to span departmental or other legacy organizational boundaries, which may not allow insight to emerge when a functional unit runs into difficulties.

Wenger and Snyder (2000) support their case with a series of checklists that shows how communities of practice differ from other groups, and where they may have an impact on organizational performance. (A comparable "cookbook" approach is to be found in Dixon, 2000.) They offer "tips" on identifying potential candidates, and on the appropriate infrastructure to allow such groups to achieve community of practice status, supported with case studies of new technology development, fixing software bugs, and leveraging knowledge in a newly expanded organization. We revisit some of these later in the section on motivation. In a subsequent review of "Communities of practice and social learning systems" (Wenger, 2000b, p. 243), the checklist is extended into a series of tables that covers "community dimensions," "boundary dimensions," and "identity dimensions." Wenger concludes with a fractal model of community: "More generally, if a community is large, it is a good idea to structure it in layers, as a 'fractal' of embedded sub-communities.... With such a fractal structure, by belonging to your own sub-community, you experience in a local and direct way your belonging to a much broader community." He cites cases of groups in Shell Oil and DaimlerChrysler.

As we note above, Xerox has fostered the community of practice as an organizational form that has been a source of innovation for a number of years. The company has developed a distinctive philosophy and managerial approach heavily influenced by Nonaka's SECI model, which provides a framework to manage the oscillation and intertwining of tacit and explicit knowledge. As also noted above, Nonaka sees middle managers as the knowledge managers in any organization. A recent case study from Xerox (Storck \& Hill, 2000) describes a community of practice that links 
middle managers from a number of functional groups working on innovative solutions to a specific long-term problem. Jubert's (1999) account of communities of practice in Siemens reveals a more formal arrangement, where, as in the case of Shell described by Wenger (2000a), managers select group members and foster participation on the basis of observations of prior competence. Hamel (2000), in contrast, in a study of a radical community of practice in IBM, describes what is almost an underground group, reminiscent of earlier descriptions of "skunkworks," or design groups who are given freedom to work outside established corporate structures.

Many of the perspectivist studies are uncritical, with a focus on "how to do it good," rather than on identifying what factors in communities of practice might work in what ways. Two exceptions to this trend within the performative, or managerialist, tradition are provided in the papers by Lam (2000) and the monograph by Baumard (1999), both of which deal overtly with the subject of tacit knowledge. The first is an ambitious attempt to place our understanding of both tacit and explicit knowledge in the context of micro- and macro-level institutionalism; critiquing the Western emphasis on explicit knowledge and its associated reward structures. The second offers sustained and detailed case studies of four very different organizations-Qantas, Indigo, Indosuez, Pechineydemonstrating that the effects of participation in relevant communities of practice are highly specific to the domains involved.

\section{The Interpretive Approach}

The interpretive approach has its roots in design work, and several of the case studies that we reference below were undertaken as humancomputer interaction (HCI) work. These studies aim to provide an explanation of communities of practice, rather than a template or blueprint for exploitation. Such work exploits a number of ethnographic methods and frameworks: activity theory, actor network theory, discourse, and conversation analysis. The first of these can provide a comprehensive account as it embraces concepts of activity, action, operations, community, artifact, and rules (Kuutti, 1996). Although there are studies at the level of the firm that use these methods to analyze the interactions of different internal communities (the accounts of Schlumberger by 
Bowker [1994], and the Salk laboratory by Latour and Woolgar [1979]), we focus here on micro-level local studies. In some fields (engineering, journalism, high-energy physics), a portfolio of such work is emerging, which may provide an opportunity for deep and informative empirical analysis of communities of practice in these sectors. Such a corpus has emerged in the Danish National Research Laboratory, where a series of studies has explored multiple aspects of engineering practice (e.g., Hertzum \& Pejtersen, 2000; Pejtersen \& Albrechtsen, 2000). These draw heavily on the methods of cognitive systems engineering (Rasmussen, Pejtersen, \& Goodstein, 1994, pp. 68-69), which emphasize detailed understanding of work domain activities by means of systematic meansends analysis, focusing on "prototypical tasks, situations based on domain characteristics, and typical decision tasks."

A number of recent studies of engineering communities draws on distributed cognition, actor network theory, and activity theory. As we indicate earlier, Fox (2000) criticizes current thinking on communities of practice for failing to address adequately social dynamics; and suggests that actor network theory may allow a more realistic exploratory framework. An example of this political approach is provided by Suchman's (2000) account of the processes of alignment that allow diverse engineers (from different communities of practice) to work together to build a bridge. Activity theory offers a further analytic framework that is hospitable to political analysis. Blackler and his colleagues (Blackler, Crump, \& McDonald, 1999, 2000) use the approach because it elicits inconsistencies, paradoxes, and tensions, which may offer opportunities for organizational learning. Engeström (2000) suggests that the framework is applied at too high a level in their study of organizational change in a high-tech manufacturing firm, and provides a reanalysis of the case focusing more specifically on the description of activities, tasks, and operations.

The journalism community has been analyzed in a number of ethnographic studies (e.g., Fabritius, 1998; Macaulay, 1999). Macaulay (1999), using activity theory and taking a national newspaper as her context, demonstrates that the "source" (a complex entity) is the unifying artifact in this community, where different colleagues must work together to validate the information that feeds into the creation of a news item. Baumard (1999) explores the case of the editor of a highly specialized 
newsletter that handles competitor intelligence, and shows how individual decision making both shapes and is shaped by the sources in the domain.

\section{Motivation}

Discussions of motivation to participate in communities of practice fall into two broad classes, underpinned respectively by a market philosophy (Sawyer, Eschenfelder, \& Heckman, 2000) and a philosophy of care. Beer and Nohria (2000) make a comparable distinction between "e" (economic value) and "o" (organizational capability) worldviews. Those motivated by a market philosophy are likely to participate on the basis of a calculus of reciprocal benefit, described by some analysts in terms of game theory (Axelrod, 1997). Reciprocity may be direct, or indirect, where "acts of kindness are returned not by recipients, but by third parties" (Nowak \& Sigmund, 2000, p. 819). This has been described as "image scoring" by Wedekind and Milinski (2000). Similar motivations have been described in analyses of situational trust in team formation; that is trust based on the assessment of risk involved in accepting the collaboration, the perceived benefit of the proposed exchange, the perceived competence of the partner, and the moral significance of the exchange (Lewicki \& Bunker, 1996). How these may operate in the online world (and how they might be compressed) is an issue to be explored in the discussion of online communities of practice later in the chapter. It may be that computer agents will operate using such calculations. We can see such a calculus at work in a number of prescriptive studies of community formation.

Factors that motivate people to codify and share knowledge for the benefit of others have been identified as a priority area for knowledge research (Holsthouse, 1998, p. 277). Such research can respond to corporate goals identified by earlier studies of knowledge management and organizational learning. Cohen (1998, p. 27), for example, refers to 100 knowledge projects, most of which had as one of their three main aims that of developing "a knowledge-intensive culture by encouraging and aggregating behaviors such as knowledge sharing (as opposed to hoarding) and proactively seeking and offering knowledge." Since innovation driven by knowledge creation is achieved by groups, there is a "need to 
examine more closely both tacit knowing and creativity as they are expressed by members of groups-singly and collectively" (Leonard \& Sensiper, 1998, p. 115).

Willingness to share anything usually depends on reciprocity. Nowak and Sigmund (2000) identify two types of reciprocity: (1) direct-two individuals associate long enough for each to play roles of receiver and giver of favors; (2) indirect-third parties donate favors without the expectation of a return from the receiver. Third party donors, while not anticipating immediate compensation for favors granted, tend to anticipate repayment at a later date in the form of a favor from another third party. There must be an exchange at some point, otherwise donors will withdraw their participation: They will not support free riders (Dyer \& Nobeoka, 2000, p. 349).

\section{Reward and Recognition as Factors in Motivation}

Samitt (1999, p. 50) argues that "Knowledge management strategies need to be linked to people by building reward and recognition programs to encourage employees to share best practices, strategies, and ideas." Others support this view; for example:

knowledge management initiatives should incorporate effective change management focussed on ... the "What's in it for me?" question. You can't force people to learn or share precious knowledge. You have to motivate them, even seduce them, show them the importance and reward their sharing activities. Develop an appropriate reward system and incentive scheme to get the message across that knowledge and learning are crucial to the sustainability of the business.

(van der Spek \& Kingma, 2000, p. 27)

An organization might explicitly offer to repay individuals who engage in knowledge sharing activity in the form of a "hard" tangible benefit, such as enhanced pay. At the other end of the scale, employees are rewarded in more subtle ways, for example, in enjoying the personal satisfaction of holding membership in a thriving knowledge-sharing community. Since "knowledge can only be volunteered ... [and] cannot be 
conscripted" (Snowden, 2000, p. 9), individuals and teams decide whether any reward offered matches the value of knowledge sharing: "People's time and energy are limited and they will choose to do what they believe will give them a worthwhile return on those scarce resources" (Cohen, 1998, p. 31). Some rewards are more appropriate for individuals than for groups and vice versa. Those identified in the literature are outlined here. Though much of the literature focuses on individuals, there are some examples of incentives that are targeted at the building of community.

\section{Economic Rewards}

Perhaps the most obvious explicit reward systems are those that involve economic incentives such as increased pay or bonuses in the forms of cash or stock options. Beer and Nohria (2000), for example, demonstrate how straightforward economic incentives offered to individuals encouraged organizational change at Scott Paper in the 1990s. They state that "proponents of this system argue that financial incentives guarantee that employees' interests match stockholders' interests" (Beer \& Nohria, 2000, p. 137).

Systems for awarding economic rewards for knowledge sharing are not necessarily tied to financial indicators such as increased revenue or stock values. Beer and Nohria (2000) highlight companies that work on commitment-based contracts with their employees. Such incentives might include a skills-based pay system and shared rewards in order to pull all workers into a shared community of purpose. The idea is that individuals are motivated through commitment, and pay is used as a fair exchange.

\section{Access to Information and Knowledge as Reward: Social Capital}

Another tangible reward of participating in knowledge-sharing ventures is access to the information and knowledge shared by the other partners, or the creation and management of social capital (Lesser \& Prusak, 2000). There is "the expectation ... that one will get valuable knowledge in return for giving it ... you need to contribute knowledge to 
become part of the knowledge networks on which your success depends" (Cohen, 1998, p. 31). This is illustrated well in the case study of the motor parts manufacturers where "any production-related knowledge that Toyota or a supplier possesses (cost, quality, inventory management, etc.) is viewed as accessible to virtually any member of the network (with perhaps the exception of a direct competitor) because it is, in effect, the property of the network" (Dyer \& Nobeoka, 2000, p. 358.) and "suppliers are motivated to participate because they quickly learn that participating in the collective learning processes is vastly superior to trying to isolate their proprietary knowledge" (Dyer \& Nobeoka, 2000, p. 351). The price paid is a limited ability to protect proprietary production knowledge, which is deemed acceptable since "intellectual property rights reside at the network, rather than the firm, level" (Dyer \& Nobeoka, 2000, p. 358). "Free riding" is prevented through established rules that forbid suppliers access to Toyota's knowledge until they explicitly agree to share their knowledge (Dyer \& Nobeoka, 2000, p. 351).

\section{Career Advancement/Security Rewards}

Career advancement can be tied to various factors, including the extent to which individuals hoard or share their expertise. Von Krogh (1998) describes one scenario:

When organizational members' futures with the company are dependent on the expertise they demonstrate, and not on the extent to which they actually help others, individuals will attempt to build up and defend their own hegemonies of knowledge ... In this competitive context, sharing more knowledge than necessary will lead to reduced power and influence. The individual will not be motivated to make his knowledge explicit or shareable unless there are clear transactions that would make this favorable. He will judge the knowledge sharing as a transaction, knowledge shared being based on expected returns.

(von Krogh, 1998, p. 140)

It is argued, therefore, that career advancement should become an explicit reward for knowledge sharing. In providing this incentive to staff, firms reward an individual performance, as well as the act of 
helping other colleagues to perform well. This is already the case in a number of firms. For example, at McKinsey and Andersen Consulting (now Accenture), partnerships are awarded on the basis of votes cast to individuals by their colleagues, which in turn are dependent more on the degree to which individuals have cooperated in the workplace than on their ability to compete (Hargadon, 1998, p. 225).

The guarantee of future work also motivates people and organizations to operate in particular ways. For example, in the study of the inter-firm network of motor component suppliers membership of the supplier association for a number of firms was sought "primarily to demonstrate ... commitment to Toyota in the hopes that Toyota would reward them with more business" (Dyer \& Nobeoka, 2000, p. 363).

\section{Enhanced Reputation as Reward}

Nowak and Sigmund (2000) explain that a human obsession with reputation and status lies behind an important "soft" reward for knowledge sharing-acknowledgment from our peers: "we feel cheated when our good deeds go unnoticed, and refrain from bad deeds lest they become known" (Nowak \& Sigmund, 2000, p. 819). This is borne out in the literature. Hargadon (1998), for example, quotes an engineer at the design firm IDEO who describes the benefits of spreading about knowledge and skills as higher visibility and winning the reputation of being an attractive work colleague. Similarly, at Unilever, flattery worked when pulling staff together for project work: "the compliment of being invited to participate in ... workshops, and after that being involved in global strategic projects [on the basis of an established reputation], was perceived as immensely rewarding" (von Krogh, 1998, p. 147). Tiegland (2000, p. 173) describes a similar phenomenon in the context of a community of programmers: "programmers were under a form of social pressure from their external community to help fellow members solve their difficult problems, often attempting to 'show off' in front of the others." At times, high performance in the external community of practice jeopardized performance in the internal community of the workplace. If conditions do not protect reputation, for example, when injustices such as idea stealing are tolerated, people are more likely to "establish their hegemonies of knowledge and protect their turf" (von Krogh, 1998, p. 142); and 
knowledge sharing activity is diminished. Judge, Fryxell, and Dooley (2000) found that reputation is one of the most important factors in motivation in high performance corporate $\mathrm{R} \& \mathrm{D}$ environments.

Reputation building can be perceived as a long-term project. Individuals who recognize this are more likely to be knowledge sharers from the outset. This is illustrated in studies by Erdelez (2000) and Rioux (2000), who explore "shared encountering" of information for others. Some people simply gain pleasure as a result of demonstrating their own altruistic and prosocial behavior. Others enjoy seeing the positive results of their efforts:

At McKinsey, the Rapid Response Team emerged to satisfy the need to maintain interactive problem solving by promising to link anyone facing a problem with others who might have useful, related knowledge-within 24 hours. They accomplished this feat by maintaining the human connection, and the individuals involved took pride in knowing who knew what in the organization and in their ability to find the right people to solve each problem.

(Hargadon, 1998, p. 222)

Personal satisfaction, then, can motivate individuals to share their knowledge.

\section{Creating Environments for Participation in Communities of Practice}

Organizations can set up a range of incentives instead of, or in addition to, reward schemes to encourage knowledge sharing. These include making knowledge sharing part of the job of each individual within the firm, encouraging employees to work in groups as communities, allowing experimentation and risk taking in the workplace, and providing tools for these activities. Unlike the earlier examples, they do not rely on reciprocity. Aspects of each of these types of incentives are discussed below.

It is argued that knowledge sharing is more likely to be encouraged in employees who know that this is a requirement of their jobs (Davenport \& 
Klahr, 1998, p. 207). Von Krogh (1998, p. 144) suggests that there should be two sets of responsibilities for the individual: "the responsibility to acquire expertise; and the responsibility to make your help accessible to those who need it as your expertise grows." Where other incentives such as reward schemes are not in place, assigning specific responsibilities to particular individuals is more likely to encourage knowledge sharing than simply expecting people to make contributions as part of a general team effort. This was demonstrated at Citibank: "Citibank developed a technical marvel of a database but initially failed to create incentives for people to enter information into it. But when the company assigned employees the responsibility of finding and entering those practices, then they began to get entered" (O'Dell \& Jackson Grayson, 1998, p. 164).

Time spent in working hours on knowledge sharing activity should be regarded as entirely legitimate (Davenport \& Klahr, 1998, p. 207). Time should be set aside specifically for people to learn, share, and help one another: "unless capturing and sharing information are built into work processes, sharing will not happen" (O'Dell \& Jackson Grayson, 1998, p. 157).

Knowledge sharing can be formalized into a key employee role through activities such as training and systematic project debriefings (von Krogh, 1998, p. 145). Leading by example can also have an impact: "managers should, on a modest level, review information behavior by addressing individuals and key groups, and senior executives need to concentrate on setting good examples of behavior" (Davenport, 1997, p. 101). Mentoring and assisting should be highly regarded, otherwise "rational people may be unlikely to surrender the power they gain from being an important knowledge source-especially since sharing tacit knowledge requires time devoted to personal contact" (Leonard \& Sensiper, 1998, p. 123).

For those operating in communities, then, the incentives for knowledge sharing are less concrete than the output of the reward systems described earlier in this chapter. The incentives to share knowledge are identified as the carrot of the continued vitality of the community and relationships between partners, and the stick of obligation to other group members. Perhaps the most important incentives, however, are those that the participants would probably not even recognize as incentives, but rather as conditions that make knowledge transfer simple to 
achieve, i.e., the environment that supports social interaction among members. These incentives are examined in further detail below.

Participants understand that the viability of their community depends on their commitment to it. This is "embodied in the willingness of individuals to share information and knowledge with other members of the community" (Merali, 2000, p. 81). If no contributions are made, the results are drastic: The community will not live. However, each contribution to knowledge sharing increases not only common knowledge, but also the trust among community members. As trust increases, more participants become willing to share and so further contributions will be made. Dyer and Nobeoka (2000, p. 352) note that this mutual causality applies equally to group identity, "both a cause, and a consequence, of collective learning processes." Thus, a further incentive to contribute in a community is the expectation of stronger relationships with partners and access to higher quality knowledge in the future.

The debate in the literature as to how far a community should extend is pertinent to the question of vitality. In the case of online communities, it is argued that there must be controls on membership so that expertise is not diluted by those of marginal use to the community as a whole (Snowden, 2000, p. 13). However, those at the margins, such as lurkers on a listserv, can later become integrated into the main group, bringing fresh ideas: "People learn by taking a position on the periphery of skilled practice and being allowed ... to move slowly into the community and the practice involved" (Brown \& Duguid, 1998, p. 107).

Communities vary in their ability to foster knowledge-sharing activity. Von Krogh (1998) identifies environments of "care" as being most conducive to knowledge sharing. Here, "the goal of learning shifts from obtaining 'maximum grip' to reaching 'maximum leverage' on others' knowledge ... [There is] a mutual intent to help others to optimize their task performance, and, therefore, to share knowledge" (von Krogh, 1998, p. 141). Individuals are less likely to regret "giving it away" when such an incentive exists.

Sometimes the disincentive of not sharing knowledge is stronger than any incentive offered to encourage sharing. In the community setting, each originator of high-quality knowledge recognizes the threshold at which it makes sense to publish. This is determined, to an extent, by peer pressure: "I codify at the point where the socialization pressure of 
the ecology forces me to volunteer my knowledge" (Snowden, 2000, p. 16). Community members who are meshed together in relationships of codependency reach this point sooner than those who have been grouped according to similar status and interest. Communities belonging to this second group "are more susceptible to rivalries that (sic) those of codependency and knowledge exchange is frequently inhibited as a result" (Snowden, 1998, p. 14).

In any environment, knowledge sharing depends upon social interaction. It is argued that the easier it is for individuals to interact, the more likely that interactions will take place. Ease of social interaction can be achieved by using these techniques:

- Clear rules on the operation of the community: For this reason the Toyota network publishes clear rules for the community participants (Dyer \& Nobeoka, 2000, p. 364).

- Shared language: O'Dell and Jackson Grayson (1998, p. 165) demonstrate how this can be achieved through the use of a common framework for classifying information that enables "diverse units to talk to each other more effectively about their business problems."

- Social events: When individuals enjoy social relationships with their colleagues they find it easier to share knowledge on serious issues (von Krogh, 1998, p. 145). The Toyota suppliers association, for example, has a PR/sports committee to encourage friendships (Dyer \& Nobeoka, 2000, p. 353).

- Collocation of staff: Physical co-location makes it possible for individuals to communicate easily with one another (Allen, 1984). It is recognized that electronic virtual communities are essential in some disciplines, for example, biotechnology, where multiple authorship of research papers is common; and it is technically possible for people to telecommute from just about anywhere. However, "experience suggests that knowledge workers still want and need to work and live in close proximity ... the clustering of high-tech work in the Silicon Valley and the Northeast [provides] evidence that face-to-face relationships are still 
the only truly effective way to transfer tacit knowledge" (Cohen, 1998, p. 37). Certain knowledge-transfer activities that rely on factors such as observation or awareness of body language cannot be undertaken remotely (Holsthouse, 1998, pp. 277-278). This would, for instance, apply to brainstorming (Leonard \& Sensiper, 1998, pp. 118) or in cases where there is potential for misunderstanding (O’Dell \& Jackson Grayson, 1998, p. 157).

The philosophy of care, in contrast, relies on mutual regard, rather than the expectation of mutual benefit.

\section{Infrastructure}

The importance of adequate infrastructure is stressed by Wenger and Snyder (2000, pp. 144-145). The kinds of support that they outline are, in some ways, a blueprint for an organizational memory system, conceived in terms of the eclectic specification ("from storage to active remembering") offered by Bannon and Kuutti (1996). Such a specification may address some of the challenges identified in the work of earlier analysts of organizational memory (e.g., Stein, 1995), who present tacit knowledge as a major impediment to the design of fully comprehensive memory systems. "Active remembering" has inspired a number of case studies, which capture the local interplay of knowledge and memory as work unfolds when participants are not present together (Ackerman \& Halverson, 1999; Decortis, Noirfalise \& Pecheux, 1998; Sauvagnac \& Falzon, 1998). Much of our discussion of infrastructure covers issues that are pertinent to this. Although some analysts (e.g., Newell, Scarborough, Swan, \& Hislop, 2000) distinguish technological and cultural infrastructure at most, we offer a more detailed taxonomy based on work by Star and Ruhleder (1994) that may provide a better measure of the kinds of support that may be required. This involves:

- technologies for communication and representation

- "boundary objects" that are instantiated by such information and communication technologies and that may be shared by members of a group and across groups

- "social infrastructure," or the networks that are brought into play to establish, maintain or enhance position or status 
- "discursive infrastructure," the genres, or shaping stories that allow managers and other participants in practice to make sense of interactions

\section{Technologies for Communication and Representation}

A number of technologies to support group interaction and computersupported cooperative work exist, and we give examples in a later section on online communities of practice. The focus in this section is on intranets, and on the claims that have been made about their role in fostering shared or collective knowledge in communities of practice.

Individuals are motivated to act when (a) it is easy to do so (Snowden, 2000, p. 10) and (b) the usefulness of acting is obvious. The provision of a suitable technological infrastructure, such as an intranet (Brown \& Duguid, 1998, p. 98) for knowledge creation and sharing is important for this.

Brown and Duguid (1998, p. 105) are critical of new technology that is ostensibly meant to help knowledge management efforts when in fact it simply "attends primarily to individuals and the explicit information that passes between them." They argue that tools for information sharing need to be integrated into communities and should match the levels of formality operated in the communities they serve:

The local informality found within communities differs from levels of explicitness and formality often demanded between communities ... The demands for formality demanded by technologies can disrupt more productive informal relations ... Technologies thus have to include different degrees of formality and trust ... if new technologies ask people to negotiate all their social interrelations like their banking relations, they will leave little room for the informal, the tacit, and the socially embedded-which is where know-how lies and important work gets done.

(Brown \& Duguid, 1998, p. 105)

If employers expect workers--especially those working across distributed organizations - to use corporate intranets and e-mail systems as 
"places" for informal discussion, then the design of the systems needs to reflect this:

This choice between formality and informality will have repercussions in the design of complex technologies. But it also has implications on the implementation of such things as corporate intranets and mail systems. Increasingly workplaces seek to control the sorts of interactions and exchanges these are used for. Yet these systems in many ways replace the coffee pot and the water cooler as the site of informal but highly important knowledge diffusion. Limiting their informality is likely to limit their importance.

(Brown \& Duguid, 1998, p. 106)

Kransdorff (2000, p. 78) points out that "individuals are generally better speakers than they are writers." Facilities that allow input to shared information systems that replicate patterns of speech would be expected to attract greater participation than those that require users to spend time reformatting ideas before submitting them to an electronic knowledge base. This point may explain the disappointment of those who experience initial high levels of interest in new knowledge management systems but later discover that "implementation efforts often fall victim to a 'build it and they will come' approach" (Ruggles, 1998, p. 84). At the Chevron Corporation, the company "started by creating an internal electronic database and expected people to enter their practices and contact others with intriguing solutions. The company experienced good access initially, but then usage began to trail off" (O'Dell \& Jackson Grayson, 1998, p.164).

Even if it is possible to motivate everyone to share knowledge through the provision of state-of-the-art technological tools, it is argued that some types of knowledge are unsuitable for electronic storage and retrieval. O'Dell and Jackson Grayson (1998, p. 164) suggest that "really important and useful information for improvement is too complex to put online. At Chevron this is recognized. Here the database is meant to enhance and support existing knowledge sharing mechanisms on best practice. AMP use the database as a pointer with basic information on the system and follow-up encouraged through named individuals cited on the system." 
Rather than encourage people to share information, systems may encourage people to impede such practices. It has been suggested that in some circumstances workers might actually sabotage knowledge management systems over fears of job security. When discussing the building of knowledge bases of customer support information it is noted that "support analysts may question the wisdom of furnishing their knowledge for a system if they believe that the system may someday replace their own jobs" (Davenport \& Klahr, 1998, p. 206).

Intranets implemented without due preparation and analysis (Lamb, 1999; Scheepers \& Darmsgaard, 1997) are not likely to improve organizational performance. Newell et al. (2000) describe such a case in a study of a European bank, where inadequate incentives led to lack of input. This point is corroborated in Orlikowski's (1993) analogous study of a failed Lotus Notes implementation where an existing incentive scheme made no provision for use of the novel technology (also see Schultze \& Boland, 1997). These issues are also discussed in an earlier ARIST chapter by Davenport and McKim (1995). In a recent discussion of the knowledge management concept, Swan and Scarborough (2001), suggest that an "episodic" model (the "episodes" are agenda setting, selecting, implementing, and routinization) is appropriate. "Community" is associated with the selection and implementation phases, and they warn against relying solely on intranets as a sharing mechanism.

\section{Representation}

A key problem is mutual understanding within and across local regimes (Star, 1995). In face-to-face "primitive" communities like that of the flutemakers described earlier, representation of collective knowledge is not an issue. Where members of groups are dispersed in space or time (across a site, for example, or in cases where they are members of different workshifts), representation may be a critical issue. It may be equally critical where trans-domain understanding is at stake. Salomon (1993b) states that there can be no distributed cognition without individual cognition, and that many cognitions are not distributed. The representation of individual and group understanding may be an important feature of the reciprocal interplay between them. 
Recent work on the mapping of argumentation is relevant to this problem. Eden and his colleagues (Eden \& Spender, 1998) have worked for a number of years on software applications modeling arguments that support decisions. The current version is marketed as "Decision Explorer," which can produce what are called "idiographic causal maps" (Eden \& Ackerman, 1998). Bood (1998) compares a number of approaches to argumentation mapping, drawing on earlier work by Huff (1988). Raeithel and Velichkovsky (1996), working within an activity theory framework, offer a review of a number of representational approaches (repertory grid included) that may help those who analyze collaboration in groups.

Two further bodies of work on formal representation are pertinent. The first considers ontologies (for example, Vickery, 1997); specifically enterprise ontology work (Uschold, King, Moralee, \& Zorigios, 1999) that seeks to model the diverse activities of a given domain and the capabilities and other resources to support them (Kingston \& MacIntosh, 2000). The models are presented as formal hierarchies, though the terms linked in this way may be annotated with textual unstructured descriptions. Such structures are, in effect, thesauri, suggests Soergel (1999), who has designed a generic thesaurus that might equally serve as an ontology (Soergel, 1998). By capturing dimensions of expertise-e.g., role, capability, competence and project history-these richly faceted structures can help managers identify members of teams who, jointly, embody the collective knowledge that is required to achieve a given project objective. An alternative approach is to consider documents as surrogates for expertise; specifically the generic documents that imply collective understanding in different domains (Davenport \& Rosenbaum, 2000). Pejtersen and Albrechtsen (2000) have recently presented a framework for "ecological" classification that covers dimensions of human expertise and documentation.

The second domain that can enhance representation of individual and group interaction is a body of work on XML (Extensible Markup Language) and e-commerce. This suggests that metadata may offer a consistent notation to capture local knowledge at different levels of aggregation, and thus contribute to improved interaction within domains (Attipoe, 1999). Bryan (1998) points out that XML is flexible enough to be able to describe any logical text structure, whether it be a 
form memo, letter, report, book, encyclopedia, dictionary, or database, and suggests that emerging Business Object Libraries like Common Business Language (CBL) or Biztalk will accelerate the adoption of XML as an e-commerce standard. Glushko, Tenenbaum, and Meltzes (1999) explain the design rationale for the CBL: based on an extensible public collection of generic business interface definitions, it tells potential trading partners what online services a company offers and what documents to use for those services. The library's strength lies in the fact that it is easier to interconnect companies in terms of the documents they exchange, as they already largely agree on these. Services are, in effect, defined by the documents they accept and produce. The responsibility for document definition will lie with communities of practice: Early adopting cornmunities are mathematicians, genealogists, and chemists (Green, 1999). Strong proponents of XML predict it will allow online businesses to build on one another's published content and services to create innovative virtual companies, markets, and trading communities; these can be leveraged by "comparison-shopping" agents, which can exploit the affordance of XML to rapidly configure appropriate resources (Glushko et al., 1999; Maes, Guttman, \& Moukas, 1999). Recent developments in voice-based XML (VoxML [Voice Markup Language]) may overcome reluctance by practitioners to keyboard texts into appropriate systems.

Indexing of specifications and classifications based on the categories used by participants has been proposed in a number of domains. Keiichi, Voss, Juhnke, and Kreifelts (1998) describe a concept indexing system that generates categories on the fly, using annotations made by domain specialists as they read professional literature. Hubar and Gillaspy (1998) discuss the development of an AIDS scheme that uses the terminology of patients and their helpers. In such cases, the development of an endogenous classification will have political consequences - an issue explored in depth by Bowker and Star (1999), who draw many of their examples from the world of nursing classification. Albrechtsen and Jacob (1998) have reviewed the development of endogenous schemes in different contexts (e.g., AIDS, nursing), in a study of "dialogic" or "heteroglossic" classification (also see Jacob \& Albrechtsen, 1998). These terms denote an eclectic scheme, and have none of the implications in terms of turn-taking that a conversation analyst, for example, might 
invoke. Jacob and Shaw (1998) provide a comprehensive review of sociocognitive perspectives to representation in an earlier ARIST volume.

\section{Boundary Infrastructure}

Where such schemes are designed to support inter-domain understanding, they may be considered "boundary objects" (Albrechtsen \& Jacob, 1998). The term was introduced in 1989 by Star and Greisemer (1989), who proposed that a class of objects provides common ground for different social actors to work together. Boundary objects may be artifacts, texts, prescriptions, classification systems, or indexes, and are, to some extent, protean: "plastic enough to adapt to local needs, and the constraints of the several parties employing them, yet robust enough to maintain common identity across sites" (Star \& Greisemer, 1989, p. 393). Individuals may also be part of boundary infrastructure, where they contribute to the diffusion of knowledge across and between communities (the traditional gatekeeper role). One approach is to foster a specific organizational role, "the broker." This role within the firm is treated in depth by Wenger (2000b, pp. 235-236), who classifies brokers into three types: "boundary spanners" (comparable to Berkenkotter's [1995] "key informants," trusted authorities in a number of fields), "roamers," and "outposts." The role of brokers is explored at the level of the firm (and of inter-organizational knowledge sharing) by Hargadon (1998). As we note above, Nonaka and Konno (1998) suggest that the role of the broker is essential to the innovative interplay of tacit and explicit knowledge. Such brokering is assigned to middle managers in the "ba" model, the group most likely to be lost in re-engineering initiatives.

In addition to boundary objects and brokers, Wenger proposes that boundary interactions are an important feature of the diffusion process, and that these can be managed or harnessed in the interests of innovation (Wenger, 2000b, pp. 236-238). He offers examples of simple mechanisms (online and off-line): sabbaticals, visits, seminars, and, at the periphery, help desks, FAQ lists, "visiting rooms," and fairs. At a more formal level, organizations may foster cross-disciplinary projects. 


\section{Social Infrastructure}

By "social infrastructure," we refer to networks of contacts (online and off-line), and what is transferred by means of these networks. As we indicate above, levels of diffusion may depend on the social capital established in professional and working networks, although the efficacy of different types of network may vary across sectors, or even across groups within firms. The nature of the bonds and relationships that link members of communities of practice can be explored with the help of a body of work on social networks (Garton, Haythornthwaite, \& Wellman, 1998; Haythornthwaite, 1996, 1999). These suggest that participants in networks operate with a portfolio of relationships, whose density varies according to their purpose in belonging to the network (Wellman \& Gulia, 1999).

Studies of the role of weak and strong ties in fostering innovation have been inconclusive. (Lam [2000] offers a skeptical analysis of different types of institutional networks and their respective innovation potentials.) Some communities of practice appear to draw their strength from the weak ties that link participants (Granovetter, 1973). In such cases, less intense networks are more wide-ranging, and thus offer more cross-fertilizing power. Intensity of relationship in communities of practice may be linked to a time frame. Lewicki and Bunker (1996) suggest that interpersonal trust develops as a three phase process, which moves from surface interaction to intimacy over time. Ties are likely to be strong where members of a community practice have bonded in apprenticeships (traditional situated learning) in closed communities like the print shop (von Krogh, et al. [2000] "high care" knowledge environments); and although such ties may reinforce the knowledge of the community, they are unlikely to foster innovation. Wenger and Snyder (2000) describe such a high care social infrastructure in the case of an officially endorsed community of practice at American Management Systems. Participants must contribute one knowledge development project a year. In return, their participation is "paid for by their business units, which fund their annual projects, cover their attendance at workshops, and send them to an annual conference that brings together all the company's communities of practice" (Wenger \& Snyder, 2000, p. 144). 


\section{Discursive/Narrative Infrastructure}

If, as Wenger suggests, stories or narratives are a critical component of identity in communities of practice, how, then, may the creation and recording of stories be supported? Undertaking the eliciting, capture, and analysis of stories is not a trivial task. A review of work in this area is provided by Boyce (1996), and Clayman and Maynard (1995) provide an account of methodologies. Deuten and Rip (2000, p. 69), for example, claim that "agency appears only in, and through, narrative," and that understanding the constitutive role of narrative in an organization is a fundamental managerial competence. By analyzing what they call narrative infrastructure (the "rails along which multiactor and multilevel processes gain thrust and direction") in a case study of product innovation in a biotechnology firm, they show "how actually, over time, attribution and typicifaction in stories, and the implied stories contained in interactions link up, and an overall plot emerges." They thus identify a narrative infrastructure that enables, as well as constrains, further actions. A linear storyline reduces complexity: "a variety of accounts, formal and informal, technical and social, strategic and operational, for internal and external purposes" (Deuten \& Rip, 2000, pp. 70-71). One can inquire how these accounts evolve along the "journey of innovation," and why they can become more linear over time. As Callon (1991) has pointed out, linearity fixes events-the linear narrative is irreversible, and is thus an extremely useful managerial tool. Suchman and Trigg (1993, p. 177) provide an account of "pseudo-narratives" in an AI community that "are constructed for the specific purpose of reconstructing common sense knowledge as something that can be transparently read off of the particular technical representations to hand." A comparable (and much cited) account of narrative in an office supply firm is offered by Boje (1991).

\section{Narrative Infrastructure and Working Memory}

In explaining how coherence can emerge in a multiactor, multilevel process, without any one actor specifically being responsible (a form of organizational knowledge), Deuten and Rip (2000, p. 72) stress that 
narration, rather than text, must be the focus of attention. This is because "narration occurs in interactions, informs and shapes them, and makes action into something memorable." This proposition is consistent with Bannon and Kuutti's (1996) presentation of the concept of active remembering, mentioned above. Deuten and Rip (2000) invoke Schön's (1983) observation that naming a situation or a problem as something recognizable mobilizes resources from past experience. Such observations are consistent with other analyses of organizational memory that have moved away from a repository approach (Stein, 1995) to an exploration of how an archive may intersect with understanding that emerges in activity (Ackerman \& MacDonald, 1996; Cross \& Baird, 2000; Morison, 1997). Writing with a design focus, Marshall, Shipman, and McCall (2000) present community memory as a cyclical process that involves seeding, evolution, and reseeding, and they describe interfaces that allow capture of insight on the fly. As we note above, comparable accounts of the emergence of memory in narrative transformations are offered by Sauvagnac and Falzon (1998), in a case study of medical diagnosis, the outcome of a process of team observations and transformations reflected in an evolving record as it migrates across different specialist groups. This is one of a number of studies of medical matters based on the theme of "good organizational reasons for bad records." (See, for example, Bowker and Star, 1999.) Where markers of the transformation are available (in the form of annotations in the paper record, for example), the resulting history can afford a more detailed understanding in cases of "handover" or "changeover" where documentation is a critical boundary object (Decortis et al., 1998). Many attempts to formalize medical records have been less successful than anticipated, because of lack of annotation. Current design work on annotating electronic documents may overcome the problem (Churchill, Trevor, Bly, Nelson, \& Cubranic, 2000).

We can see similarities between narrative infrastructure or "the evolving aggregation of actors/narratives in their material and social setting, that enables and constrains the possible stories, actions, and interactions by actors" (Deuten \& Rip, 2000, p. 74) and Wenger's shared repertoires that contribute to shared identity in communities of practice. Another pertinent concept is the "industry recipe," which Tsoukas (1996) develops in his discussion of organizations as sites of distributed 
knowledge. An industry recipe is a discourse developed over time within a particular industry. The recipe is learned within the context of discursive practices; it reflects the tacit knowledge of those involved in practice, and can offer guidance to managers faced with the problem of what Tsoukas describes as the tension between expectation, (personal) dispositions, and interactive situations. How a manager understands a recipe is always influenced by immediate circumstances and local agendas. Tsoukas describes organizational knowledge as distributed because it is always incomplete (those involved cannot know all that they need to know), and always spread across contexts and organizational members. The key to coordinated action, he maintains, is not an overview from the top, but that those "lower down" find more and more ways of getting connected and interrelating the knowledge that each one has (Tsoukas, 1996, p. 22). We can see similarities between "industry recipes" and Alexandrian pattern libraries of the sort described by Falconer (1999) and Bayle et al. (1998). The patterns are more or less formal representations of responses to recurrent problems in social space, and can be used in situated design work. We discuss some novel, local representations of this sort in the next section.

\section{Online Communities of Practice}

In this section, we consider the contentious case of online communities of practice. Not all online communities are communities of practice. As Lutters and Ackerman (1997) point out: "It is assuredly premature to attribute community to the full range of Net life" (p. 41). They proffer the term "collectivity" to describe the "full range of communities, clubs, groups, gangs, church associations, building societies, skidrow hotels, and so on that will exist in the Net" (p. 41). Davenport and Hall (2001) suggest that if communities of practice are indeed sites for organizational learning, it may be possible to define them in terms of a framework. They provide a tentative model taking distributed cognition, situated learning, situated action, and social infrastructure as quasinormative characteristics that distinguish online communities of practice from their material or hybrid counterparts, and use this to evaluate three empirical projects (Davenport \& Hall, 2001). 
Teigland (2000, p. 171) observes that online communities "exhibit many of the characteristics of material communities of practice-reciprocity, identity, and so on-but the individuals involved have never typically met, and they work through what is by definition a codified exchange of information, which goes against other aspects of the theory." They, thus, fail to exhibit the defining characteristics of face-to-face interaction and tacit knowledge. Teigland suggests that current defining criteria may need to be revised. Secondly, an online community of practice may be ephemeral (Wolf, 1997), and the knowledge created may be lost where innovative local practice is uncoupled from an organization that might use it, unless infrastructure, which can sustain what may be learned, is in place. The world of software design has provided some of the most compelling examples of online communities to date. Sawnhey and Pirandelli (2000) discuss this sector in terms of "communities of creation," and offer a taxonomy that covers open, closed, and gated communities. Sun MicroSystems' Community Source License (SCSL) is presented as an exemplary partially open system that has "specific rules for membership, a sponsor, and a system for managing intellectual property rights that allows members to benefit from the intellectual property they help to create" (Sawnhey \& Pirandelli, 2000, p. 42). These authors conclude that the creativity of such communities will be strongest where the infrastructure includes mechanisms for rewards, but rewards at the level of the community, rather than of the individual (by means, for example, of a license that allows members to mutually exploit the innovations that they have contributed to-a form of monetized social capital).

Design work contexts other than the software industry also provide examples of online communities of practice. Yates and Sumner (1997) offer two case studies that support the proposition that genres act as stabilizers that counteract centripetal and centrifugal tension in groups supported by computer-mediated communication (CMC). In the first study, they use techniques from conversation analysis to show how micro-genres emerge in a discussion list, not strictly a community of practice. The second case, however, is a study of a cross-disciplinary design community, and the reworking of community genres by one of the designers, in a response to a less than optimal previous genre repertoire. "As the community recognized common breakdowns in the design process, they improved their representations to overcome these 
breakdowns. The outcome was a progression toward well-defined design representations that made explicit significant objects and their relationships" (Yates \& Sumner, 1997).

Hildreth and Kimble (1999) describe the development of a planning document (an amalgam of multiple "soft knowledge" inputs from different teams) in a transcontinental project, focusing on the document's role as an infrastructural boundary object in a community of practice. The document "bounded" internal differences (national and cultural) and acted as a "collaborative catalyst" (Hildreth \& Kimble, 1999, p. 23). Although the planning document could be most fully interpreted by "old timers" who were familiar with the knowledge of previous generations embedded in the artifact, Hildreth and Kimble comment on its usefulness in situated learning. Nonnecke and Preece (1999) have studied lurkers on online discussion lists, a practice that appears to be a form of legitimate peripheral participation.

Online communities raise a number of issues related to "intricacies of design" (Mynatt, Adler, Ito, \& O'Day, 1997) in terms of providing cues and markers for participants. Social and conversational rhythm (Erickson, 1997) is an important factor in community cohesion, and designers must accommodate the complicated management of markers for participants whose activity bridges virtual and physical space. Help for "newbies" who must learn to find their way is an important component of situated learning in such communities. Although many online communities exist to allow their members to inhabit alternative personae (Turkle, 1996), real life (RL) identity matters in most organizational interactions, and information on the presentation of the self should be provided. Reed (2001), in an analysis of the process of making conversation on a Web-list, shows how ignorant behavior by a newcomer can provoke strong negative reactions. The projects described by Mynatt and her group lie outside the commercial context. These were undertaken at Xerox PARC and elsewhere (Mynatt et al., 1997). Bobrow (1997), the codesigner of one of these (Puebio), summarizes the project as shifting from 2D (the text message) to $3 \mathrm{C}$ (community, coordination, collaboration). Designing for $3 \mathrm{C}$ is not a trivial matter. Even within a focused and small group, differences will arise over issues like privacy or connection management (Dourish, 1997; Kendall, 1999): "patterns of homogeneity and individuality, and the tension between them, present 
challenges for design that are both subtle and critical" (Dourish, 1997, p. 39 ). Such issues are managed by protocols and codes in the world of MOOs (MUD, Object Oriented): Naper (2001) presents an analysis of interaction in the virtual fantasy world of Patagonia (rendered in the Active Worlds platform), whose actors might be justly described as members of a community of practice. Holmström and Jakobsson (2001) discuss the affordances of different media in a case study of Active Worlds as a platform to design learning communities.

Online communities also test the concept of social capital, or as Lesser (2000, p. 4) describes it, "the wealth (or benefit) that exists because of an individual's social relationships." This concept emerged outside the context of organizational practice (see, for example, Blanchard \& Horan, 2000), but is now invoked by workplace analysts (e.g., Coleman, 2000). Social capital implies accumulation over time. Such accumulation may be observed where online communities persist (for example, Internet groups that consolidate peer-to-peer interactions in sectors like health care) because they represent solutions to long-term or persistent problems. Other online communities are less stable. Web shoppers, for example, present an interesting challenge to the community of practice framework, as the communities of practice involved are highly specific (e.g., eBay), and, in some cases, extremely short-lived. However, the practices that have been identified in the other case studies as conducive to the creation of knowledge in communities of practice can be observed here (McWilliam, 2000). These include:

- accelerated apprenticeship

- micro-level situated action that solves ad hoc problems

- boundary objects in the form of novel representations and forms (new genres like the Web-Ring, for example)

- social infrastructure in the form of recommender systems

- track records (Wexelblat, 1999; Wexelblat \& Maes, 1999)

- brokers who can partner those with shared tastes or partner consumers and products; they can capture and disseminate the insights that consumers provide either across communities of practice, or to vendors and designers (Maes et al., 1999), blurring the boundaries of demand and supply in an increasingly intimate form of product or service codevelopment (Cronin \& Davenport, 2001) 
In a speculative article on the real value of online communities in the context of e-commerce, Armstrong and Hagel (2000) identify four types (communities of transaction, of interest, of fantasy, and of relationship) that can meet multiple social and commercial needs; commercial success is likely to be associated with companies that can satisfy such needs with products that embody most or all of these types of community. These authors suggest that moderators or sysops in this context are, in effect, conversation managers. The problem of capturing insight from what are in several instances floating communities (they are not tied to a formal institution) is, in some cases, already being solved by the emergence of brokers who will scavenge the Web for intellectual commodities (McVeigh, 2000). Strong proponents of computer agents consider their remit in terms of this type of role (Marsh \& Meech, 2000). Where the consumer community of practice is broken down into component parts in this way, we see the apparent emergence of demand chain management, with the elements of the creation and diffusion of consumer insight commodified by different brokers. This raises issues of property rights and privacy. As Kollock (1999) points out, the Web blurs the distinction between public and private goods.

If online community is manifest as a long conversation (Erickson, 1997), what kind of infrastructure may capture the patterns of exchange? Technologies exist that support the spaces where such data may be captured (Internet Relay Chat, newsgroups, and electronic meeting systems); and recent work has demonstrated that interfaces based on visualizations of interaction analysis can offer rapid insight into the group process. Examples may be found in the work of Donath, Karahalios, and Viegas (1999) on the visualization of threads in online conversations; visualizations of turn-taking in the work of, among others, Millen and Dray (1999); and recent work of Erickson and his colleagues on participation in conversation circles (Erickson, Smith, Kellogg, Laff, \& Richards, 1999).

At a more formal level, the formation of insight in online communities of practice may be supported by a structured database environment, like Lotus Teambuilder (Yates \& Sumner, 1997), which builds on the concept of genre systems (nested sets of genres that capture typical interactions), or the shared-notetaking environment described by Landay and Davis (1999). Visualization may contribute to the success of such systems, and 
Greene, Marchionini, Plaisant, and Shneiderman (2000) describe an interface that provides multiple points of view to support complex document management. A further example of more structured support is GSweb (Romano, Nunamaker, Briggs, \& Vogel, 1998), a Web version of a complex groupware system with over ten years of development history behind it. A predecessor product designed by the group, GroupSystems, drew on standard genres for decision making (brainstorming, ranking, voting), supplemented over the years by dialogue boxes, e-mail, and other relevant digital genres. The GSweb prototype develops the idea of a collaborative portfolio further, combining tools that categorize and converge on key issues (translation tools, in other words) with tools that can offer a process overview (coordination). The principal representation device is the folder, nested and structured and accessed in Windows sequences. In addition, GSweb, like its predecessor GroupSystems, provides "tools for thought"-categorizer, outliner, commenter, and voter. Categorizer may be agent-based. Group outliner may produce an ontology for any given community whose work is embodied in the GSweb application. It is not yet clear to what extent such infrastructures may compensate for intuitive understanding of categories and cues that characterizes effective face-to-face interaction. As we note above, some analysts (e.g., Swan \& Scarborough, 2001) are skeptical that information and communication technologies, per se, can contribute to community formation.

\section{Conclusion}

There is a growing recognition among analysts that the interplay of tacit and explicit knowledge is a critical factor in organizational learning, and a primary task of managers is the conversion of (tacit) human capital into (explicit) structural capital (Edvinsson, 1997). Together, these constitute an organization's intellectual capital (see the chapter by Snyder and Buerk Pierce in this volume), and social capital is an important component of this (Nahapiet \& Ghoshal, 2000). Communities of practice, as we indicate at the start of this chapter, have been identified as the site where this alchemy can occur. From a performative perspective, they provide a means of constructing "recipes" for knowledge development: it is a matter of putting certain structures in place (an intranet, for example, and an appropriate incentive structure) and allocating personnel to communities, 
where they will work together and make insights available in appropriate knowledge bases. From a constructivist perspective, communities of practice, like other socio-technical systems, provide useful explanatory frames to study the development of collective knowledge (Kling, McKim, Fortuna, \& King, [2000] offer the alternative term "socio-technical interaction networks"). In research terms, however, their status is ambivalent: The performative approach has not been supported by systematic inquiry, and the effectiveness of the constructivist approach at a level beyond the local case study has not been established.

In what ways, then, is the topic of "organizational learning and communities of practice" relevant to ARIST? From a technology point of view, communities of practice are a useful locus of design for a range of applications that support social interaction, and have raised a number of research issues, such as appropriate mix of online and face-to-face interaction, or the effectiveness of tools to represent diverse points of view or visualize different actors in a group. From an information science perspective, communities of practice are an appropriate focus for efforts to address a number of challenges. The first is how to accommodate organizational (as distinct from individual) design, an issue that has not been addressed to any great extent in information science research (however see Elliott \& Kling, 1997; Kling \& Elliott, 1994; Kling $\&$ Lamb, 1996; Lyman, 1999). With the notable exception of work on bibliometrics (specifically citation indexing and citation mapping) library and information science has focused in individual retrieval of individual documents (for more detail on citation and the representation of collective knowledge see the chapter by Borgmann and Furner in this volume). As this chapter demonstrates, an emerging body of work presented at the ISIC (Information Seeking in Context) series of conferences (Vakkari, Savolainen, \& Dervin, 1997; Wilson \& Allen, 1998) has attempted to address information seeking in context. As we note here, within this corpus, several studies consider context in terms of distributed cognition (e.g., Erdelez, 2000; Perry, 1998; Rioux, 2000).

The second challenge is how to support interactive work that brings multiple and diverse artifacts together. This problem is of growing concern in digital library research. In 1995, Marshall and her colleagues linked the concept of large-scale information resources for communities of practice to the concept of community memory, or "the open ended set 
of collective knowledge and shared understandings developed and maintained by the group." Her team explored ways to support electronic communities by means of artifacts in the same medium-"discourse, collected materials, answers to frequently asked questions, evaluations of these materials ... or sources ... as well as marginalia and annotations, alternative organizations of materials, filters and well-tuned queries" (Marshall et al., 2000, pp. 227-228). Comparable digital libraries work has been reported by Bishop, Neumann, Star, and Merkel (2000) who have identified issues for digital library design in recent discussions of "assemblages" (the artifacts, knowledge, practices, and community influences that shape library use) and infrastructure. They introduce the concept of document streams to describe material in digital libraries, where the distinction between genres, documents, and document surrogates may be blurred, and where new document structures are likely to emerge (Solomon [1998] has used the term "information mosaic" in a comparable context). In such a context, the role of boundary spanner may be crucial: Murphy (2001), for example, has recently presented two vignettes of engineers in the aerospace industry, who act as transformers of information across artifacts in online and face-to-face mode, and whose tacit knowledge contributes to the effective use of fragmented explicit resources. In attempting to place their work, Murphy found a community of practice approach helpful, because she was able to interpret their role as broker or boundary worker of the sort described by Wenger.

A third challenge to information science that can be explored in studies of communities of practice is how to address the accumulation and management of social capital. Inter-community sharing of knowledge in digital environments raises issues of legitimacy, credibility, and authority that are different from those in traditional environments. This area is explored in detail by Van House in an extended case study (Schiff, Van House, \& Butler, 1997; Van House, 2001) of environmental planning that addresses all three of the challenges outlined above. The community in this case was composed of diverse organizations, whose understanding of a heterogeneous collection of materials supported by a digital library varied greatly. The most problematic issue in this case study was the creation and maintenance of social capital. Respondents expressed concern about de-contextualization, or inappropriate use of 
data produced by one community by those outside it, and about the opportunity costs of "productizing" their knowledge, or cleaning data, and creating documentation and metadata. Respondents were also worried about the credibility of the data, and conflicts of interest between computer experts and content specialists (Van House, in press). One way to overcome such tensions, as we suggest here, is to make the digital library, itself, the focus of a community of practice that can address such issues as they arise.

We conclude that the topic can be aligned with a number of studies in the information science domain that focuses on the ecology and ethology of the workplace (e.g., Bishop, Buttenfield, \& Van House, 2001; Bishop \& Star, 1996; Davenport \& Cronin, 1998; Lyman, 1999; Lynch 1999; Nardi \& O’Day, 1999; Sonnenwald, 1998). There is a shared perception among those who work on such studies that practice and resources mutually shape each other in the workplace. The community of practice is a compelling unit of analysis because it (1) allows socio-technical interactions to be observed at a number of different organizational levels, and (2) serves as a boundary object that pulls together insights from a number of disciplines in the interests of improved design.

\section{Bibliography}

Abbott, A. (1988). The system of professions: An essay on the division of expert labor. Chicago: University of Chicago Press.

Ackerman, M., \& Halverson, C. (1999). Organizational memory: Processes, boundary objects, and trajectories. In R. Sprague (Ed.), Proceedings of the 32nd Annual Hawaii International Conference on System Sciences (CD ROM). Los Alamitos, CA: IEEE.

Ackerman, M. S., \& McDonald, D. W. (1996). Answer Garden 2: Merging organizational memory with collaborative help. Retrieved February 5, 2001, from the World Wide Web: http://www.ics.uci.edu/ ackerman/pub/96b22/cscw96. ag2.html

Albrechtsen, H., \& Jacob, E. (1998). The dynamics of classification systems as boundary objects for cooperation in the electronic library. Library Trends, 47, 293-312.

Allen, T. J. (1984). Managing the flow of technology. Cambridge, MA: MIT Press. Armstrong, A., \& Hagel, J. (2000). The real value of online communities. In E. L. Lesser, M. A. Fontaine, \& J. A. Slusher (Eds.), Knowledge and communities (pp. 85-95). Oxford: Butterworth-Heinemann.

Attipoe, A. (1999). Knowledge structuring for corporate memory. Markup Languages: Theory and Practice, 1(4), 27-36. 
Axelrod, R. (1997). The complexity of cooperation. Princeton, NJ: Princeton University Press.

Bannon, L., \& Kuutti, K. (1996). Shifting perspectives on organizational memory: From storage to active remembering. In R. Sprague (Ed.), Proceedings of the 29th Annual Hawaii International Conference on Systems Sciences (pp. 156-167). Los Alamitos, CA: IEEE.

Bargiela-Chiapinni, F., \& Nickerson, C. (1999). Business writing as social action. In F. Bargiela-Chiapinni \& C. Nickerson (Eds.), Writing business: Genres, media and discourses (pp. 1-32). London: Longman.

Baumard, P. (1999). Tacit knowledge in organizations. London: Sage.

Bayle, E., Bellamy, R., Casady, G., Erickson, T., Fincher, S., Grinter, B., Gross, B., Lehder, D., Marmolin, H., Moore, B., Potts, C., Skousen, G., \& Thomas, J. (1998). Putting it all together: Towards a pattern language for interaction design. Summary report of the CHI'97 Workshop. SIGCHI Bulletin, 30(1), $17-23$.

Bazerman, C., \& Paradis, J. (1991). Textual dynamics of the professions. Madison, WI: University of Wisconsin Press.

Beer, M., \& Nohria, N. (2000). Cracking the code of change. Harvard Business Review, 78(3) 133-139.

Berkenkotter, C. (1995). Theoretical issues surrounding interdisciplinary interpenetration. Social Epistemology, 9(2), 175-187.

Bhatia, V. (1994). Approaches to genre analysis. In V. Bhatia (Ed.), Analysing genre: Language use in professional settings (pp. 13-41). London: Longman.

Bishop, A. (1999). Document structure and digital libraries: How researchers mobilize information in journal articles. Information Processing \& Management, 35, 255-279.

Bishop, A., Buttenfield, B. B., \& Van House, N. (Eds). (in press). Digital library use: Social practice in design and evaluation. Cambridge, MA: MIT Press.

Bishop, A., Neumann, L., Star, S., \& Merkel, C. (2000). Digital libraries: Situating use in changing information infrastructure. Journal of the American Society for Information Science, 51, 394-413.

Bishop, A., \& Star, S. L. (1996). Social informatics of digital library use and infrastructure. Annual Review of Information Science and Technology, 31, 301-402.

Blackler, F., Crump, N., \& McDonald, S. (1999). Managing experts and competing through innovation: An activity theoretical analysis. Organization, 6, $5-31$.

Blackler, F., Crump, N., \& McDonald, S. (2000). Organizing processes in complex activity networks. Organization, 7, 277-300.

Blanchard, A., \& Horan, T. (2000). Virtual communities and social capital. In E. L. Lesser (Ed.), Knowledge management and social capital (pp. 159-178). Oxford: Butterworth-Heinemann.

Bobrow, D. (1997). 3C or not 3C, that is the question. SIGGROUP Bulletin, 18(1), 33-35.

Boden, D. (1994). The business of talk. London: Polity Press. 
Boje, D. (1991). The storytelling organization: A study of story performance in an office supply firm. Administrative Science Quarterly, 36(1), 106-126.

Bood, R. (1998). Charting organizational learning: A comparison of multiple mapping techniques. In C. Eden \& J.-C. Spender (Eds.), Managerial and organizational cognition: Theory, methods, research ( $\mathrm{pp} .210-230$ ). London: Sage.

Bourdieu, P. (1990). The logic of practice. Stanford, CA: Stanford University Press.

Bowker, G. (1994). Science on the run: Information management and industrial geophysics at Schlumberger, 1920-1940. Cambridge, MA: MIT Press.

Bowker, G., \& Star, S. (1999). Sorting things out: Classification and its consequences. Cambridge, MA: MIT Press.

Boyce, M. (1996). Organizational story and storytelling: A critical review. Journal of Organizational Change Management, 9(5). Retrieved February 5, 2001, from the World Wide Web: http://newton.uor.edu/FacultyFolder/MBoyce/ 5CRITICA.HTM

Brown, J., \& Duguid, P. (1991). Organizational learning and communities-ofpractice: Toward a unified view of working, learning and innovation. Organization Science, 2(1), 40-57.

Brown, J., \& Duguid, P. (1993). Rethinking the border in design: An exploration of central and peripheral relations in practice. In S. Yelavich (Ed.), The edge of the millennium: An international critique of architecture, urban planning, product and communication design. New York: Whitney Library of Design.

Brown, J., \& Duguid, P. (1994). Borderline issues: Social and managerial aspects of design. Human-Computer Interaction, 9(1), 3--36.

Brown, J., \& Duguid, P. (1998). Organizing knowledge. California Management Review, 40(3), 90-111.

Brown, J., \& Duguid, P. (2000). The social life of information. Boston: Harvard Business School Press.

Bryan, M. (1998). An introduction to the extensible markup language (XML). Bulletin of the American Society for Information Science, 25(1), 11-14.

Callon, M. (1991). Techno-economic networks and irreversibility. In J. Law (Ed.), A sociology of monsters? Essays on power, technology and domination (pp. 132-161). London: Routledge.

Chaiklin, S., \& Lave, J. (1993). Understanding practice: Perspectives on activity and context. Cambridge: Cambridge University Press.

Churchill, E., Trevor, J., Bly, S., Nelson, L., \& Cubranic, D. (2000). Anchored conversations: Chatting in the context of a document. Proceedings of the CHI 2000 Conference on Human Factors in Computing Systems (pp. 454-461). New York: ACM Press.

Clayman, S., \& Maynard, D. (1995). Ethnomethodology and conversation analysis. In P. Ten Have \& G. Psathas (Eds.), Situated order: Studies in the social organization of talk and embodied activities (pp. 1-30). Lanham, MD: University Press of America. 
Cohen, D. (1998). Towards a knowledge context: Report on the first annual U.C. Berkeley Forum on Knowledge and the Firm. California Management Review, 40(3), 22-39.

Cohen, M. D., \& Sproull, L. S. (Eds.). (1996). Organizational learning. London: Sage.

Coleman, J. S. (2000). Social capital in the creation of human capital. In E. L. Lesser (Ed.), Knowledge and social capital (pp. 17-41). Oxford: ButterworthHeinemann.

Contu, A., \& Willmott, H. (2000). Comment on Wenger and Yanow, Knowing in practice: A "delicate flower" in the organizational learning field. Organization, 7, 269-276.

Cook, S., \& Yanow, D. (1993). Culture and organizational learning. Journal of Management Inquiry, 2, 373-390.

Covi, L. (1999). Material mastery: Situating digital library use in university research practices. Information Processing \& Management, 35, 293-316.

Cronin, B., \& Davenport, E. (2001). E-rogenous zones: Positioning pornography in the digital economy. The Information Society, 17(1), 33-48.

Cross, R., \& Baird, L. (2000). Technology is not enough: Improving performance by building organizational memory. Sloan Management Review, 41(2), 69-78.

Davenport, E. (1999). Implicit orders: Documentary genres and organizational practice. In H. Albrechtsen (Ed.), Proceedings of the 10th SIGCR classification workshop (pp. 45-64). Silver Spring, MD: American Society for Information Science.

Davenport, E., \& Cronin, B. (1998). Texts at work: Some thoughts on "just for you" service in the context of domain expertise. Journal of Education for Library and Information Science, 39, 264-274.

Davenport, E., \& Hall, H. (2001). New knowledge and micro-level online organization: Communities of practice as a development framework. In R. Sprague (Ed.), Proceedings of the 34th Annual Hawaii International Conference on Systems Sciences (CD-ROM). Los Alamitos, CA: IEEE.

Davenport, E., \& McKim, G. (1995). Groupware. Annual Review of Information Science and Technology, 30, 115-159.

Davenport, E., \& Rosenbaum, H. (2000). A system for organizing situational knowledge in the workplace that is based on the shape of documents. In C. Beghtol, L. Howarth, \& N. Williamson (Eds.), Dynamism and stability in knowledge organization. Proceedings of the Sixth International ISKO Conference. Advances in Knowledge Organization (pp. 352-358). Wurzburg: Ergon Verlag.

Davenport, T. H. (1997). Information ecology: Mastering the information environment. New York: Oxford University Press.

Davenport, T. H., \& Klahr, P. (1998). Managing customer support knowledge. California Management Review, 40(3), 195-208.

Decortis, F., Noirfalise, S., \& Pecheux, V. (1998). Distributed representations and collective memories in nuclear power plant shift changeover. In P. Marti \& S. 
Bagnara (Eds.), Designing Collective Memories. Proceedings of the 7th Travail Humain Workshop (11 pages). Paris: Le Travail Humain.

Deuten, J., \& Rip, A. (2000). Narrative infrastructure in product creation processes. Organization, 7, 69-93.

Dixon, N. M. (2000). Common knowledge: How companies thrive by sharing what they know. Boston: Harvard Business School Press.

Donath, J., Karahalios, K., \& Viegas, F. (1999). Vizualising conversation. In R. Sprague (Ed.), Proceedings of the 32nd Annual Hawaii International Conference on Systems Sciences (CD ROM). Los Alamitos, CA: IEEE.

Dourish, P. (1997). Different strokes for different folks: Privacy norms in three media spaces. SIGGROUP Bulletin, 18(1), 36-38.

Dyer, J., \& Nobeoka, K. (2000). Creating and managing a high-performance knowledge-sharing network: The Toyota case. Strategic Management Journal, $21,345-367$.

Eden, C., \& Ackerman, M. (1998). Analyzing and comparing idiographic causal maps. In C. Eden \& J.-C. Spender (Eds.), Managerial and organizational cognition: Theory, methods, research (pp. 192-209). London: Sage.

Eden, C., \& Spender, J.-C. (1998). Managerial and organizational cognition: Theory, methods, research. London: Sage.

Edvinsson, L. (1997). Developing intellectual capital at Skandia. Long Range Planning, 30, 366-373.

Elliott, M., \& Kling, R. (1997). Professional use of digital libraries in organizations: Case study of legal research in civil and criminal courts. Journal of the American Society for Information Science, 48, 1023-1035.

Engeström, Y. (2000). Comment on Blacker et al., Activity theory and the social construction of knowledge: A story of four umpires. Organization, 7, 301-310.

Engeström, Y., \& Middleton, D. (Eds.). (1997). Cognition and communication at work. Cambridge: Cambridge University Press.

Erdelez, S. (2000). Towards understanding information encountering on the Web. In D. Kraft (Ed.), Proceedings of 63rd Annual Meeting of the American Society for Information Science (pp. 363-371). Medford, NJ: Information Today, Inc.

Erdelez, S., \& Doty, P. (1999). Adapting knowledge management to a heterogeneous information environment: A case study of county judges and clerks in rural Texas courts. In L. Woods (Ed.), Proceedings of the 62nd Annual Meeting of the American Society for Information Science (pp. 135-145). Medford, NJ: Information Today, Inc.

Erickson, T. (1997). Social interaction on the net: Virtual community or participatory genre? In J. Nunamaker \& R. Sprague (Eds.), Proceedings of the 30th Annual Hawaii International Conference on Systems Sciences (pp. 23-30). Los Alamitos, CA: IEEE.

Erickson, T. (1999). Rhyme and punishment. In R. Sprague (Ed.), Proceedings of the 32nd Annual Hawaii International Conference on Systems Sciences (CD ROM). Los Alamitos, CA: IEEE.

Erickson, T., Smith, D., Kellogg, W., Laff, M., \& Richards, J. (1999). Socially translucent systems: Social proxies, persistent conversation and the design of 
"Babble." In M. Williams (Ed.), Proceedings of the CHI 1999 Conference on Human Factors in Computing Systems: The CHI is the limit (pp. 72-79). New York: ACM Press.

Fabritius, H. (1998). Triangulation as a multi-perspective strategy in a qualitative study of information seeking behaviour in journalists. In T. Wilson \& D. Allen (Eds.), Exploring the contexts of information behaviour: Proceedings of the Second International Conference on Research in Information Needs, Seeking and Use in Different Contexts (pp. 406-419). London: Taylor Graham.

Falconer, J. (1999). The business pattern: A new tool for organizational knowledge capture and reuse. In L. Woods (Ed.), Proceedings of the 62nd Annual Meeting of the American Society for Information Science (pp. 313-330). Medford, NJ: Information Today, Inc.

Fleming, W. (1994). Methodography: The study of student learning as situated action. In G. Gibbs (Ed.), Learning approaches evaluation and strategy: Improving student learning through assessment and evaluation (pp. 525-544). Oxford: Oxford Brookes University.

Fox, S. (2000). Communities of practice, Foucault and actor-network theory. Journal of Management Studies, 37, 853-867.

Garton, L., Haythornthwaite, C., \& Wellman, B. (1998). Studying online social networks. In S. Jones (Ed.), Doing Internet research: Critical issues and methods for examining the Net (pp. 75-106). London: Sage.

Gerson, E., \& Star, S. (1986). Analyzing due process in the workplace. ACM Transactions on Office Systems, 4(3), 257-270.

Gherardi, I. S., Nicolini, D., \& Odella, F. (1998). Toward a social understanding of how people learn in organizations: The notion of shared curriculum. Management Learning, 29, 273-298.

Ginnett, R. (1993). Crews as groups: Their formation and their leadership. In B. Wiener, B. Kanki, \& R. Helmreich (Eds.), Cockpit resource management. New York: Academic Press.

Glushko, R., Tenenbaum, J., \& Meltzes, B. (1999). An XML framework for agentbased e-commerce. Communications of the ACM, 42(3), 106-114.

Goodwin, M. (1995). Assembling a response: Setting and collaboratively constructed work talk. In P. Ten Have \& G. Psathas (Eds.), Situated order: Studies in the social organization of talk and embodied activities (pp. 173-186). Lanham, MD: University Press of America.

Granovetter, M. (1973). The strength of weak ties. American Journal of Sociology, 78, 1360-1380.

Green, D. (1999). The evolution of Web searching. In B. McKenna (Ed.), Proceedings of the 23rd International Online Meeting 1999 (pp. 251-258). Hinksey Hill, U.K.: Learned Information Ltd.

Greenberg, J., \& Dickelman, G. (2000). Distributed cognition: A foundation for performance support. Performance Improvement, 39(6), 18-22.

Greene, S., Marchionini, G., Plaisant, C., \& Shneiderman, B. (2000). Previews and overviews in digital libraries: Designing surrogates to support visual 
information seeking. Journal of the American Society for Information Science, $51,380-393$.

Hamel, G. (2000). Waking up IBM: How a gang of unlikely rebels transformed Big Blue. Harvard Business Review, 78(4), 137-146.

Hargadon, A. (1998). Firms as knowledge brokers: Lessons in pursuing continuous innovation. California Management Review, 40(3), 209-227.

Haythornthwaite, C. (1996). Social network analysis: An approach and technique for the study of information exchange. Library \& Information Science Research, 18, 323-342.

Haythornthwaite, C. (1999). Collaborative work networks among distributed learners. In R. Sprague (Ed.), Proceedings of the 32nd Annual Hawaii International Conference on System Sciences (CD ROM). Los Alamitos, CA: IEEE.

Hertzum, M., \& Pejtersen, A. (2000). Information seeking practices of engineers: Searching for documents as well as people. Information Processing \& Management, 36, 761-778.

Hildreth, P., \& Kimble, C. (1999). Communities of practice in the distributed international environment. In B. Fields \& P. Wright (Eds.), Design for collaboration: Communities constructing technology. York: Department of Computer Science, University of York.

Holmström, H. \& Jakobsson, M. (2001). Using models in virtual design. In R. Sprague (Ed.), Proceedings of the 34th Annual Hawaii International Conference on Systems Sciences (CD-ROM). Los Alamitos, CA: IEEE.

Holsthouse, D. (1998). Knowledge research issues. California Management Review, 40(3), 277-280.

Huber, J., \& Gillaspy, M. (1998). Social constructs and disease: Implications for controlled vocabulary for HIV/AIDS. Library Trends, 47, 190-208.

Huff, A. (1988). Mapping strategic thought. Chichester: John Wiley.

Hutchins, E. (1991). The social organization of distributed cognition. In L. Resnick, J. M. Levine, \& S. D. Teasley (Eds.), Perspectives on socially shared cognition (pp. 284-307). Washington, DC: American Psychological Association.

Hutchins, E. (1993). Learning to navigate. In S. Chaiklin \& J. Lave (Eds.), Understanding practice: Perspectives on activity and context (pp. 35-63). Cambridge: Cambridge University Press.

Hutchins, E. (1995a). Cognition in the wild. Cambridge, MA: MIT Press.

Hutchins, E. (1995b). How a cockpit remembers its speeds. Cognitive Science, 19(3), 265-288.

Hutchins, E. (1996). Organizing work by adaptation. In M. D. Cohen \& L. S. Sproull (Eds.), Organizational learning (pp. 20-57). London: Sage.

Hutchins, E., \& Klausen, T. (1997). Distributed cognition in an airline cockpit. In E. Engeström \& D. Middleton (Eds.), Cognition and communication at work (pp. 15-34). Cambridge: Cambridge University Press.

Jacob, E., \& Albrechtsen, H. (1998). When essence becomes function: Post-structuralist implications for an ecological theory of organizational classification 
systems. In T. Wilson \& D. Allen (Eds.), Exploring the contexts of information behaviour: Proceedings of the Second International Conference on Research in Information Needs, Seeking and Use in Different Contexts (pp. 519-534). London: Taylor Graham.

Jacob, E., \& Shaw, D. (1998). Socognitive perspectives on representation. Annual Review of Information Science and Technology, 33, 131-186.

Jones, M. (1997). Successful corporate communities: All communities are not the same. SIGGROUP Bulletin, 18(2), 31-32.

Jubert, A. (1999). Developing an infrastructure for communities of practice. In B. McKenna (Ed.), Proceedings of the 19th International Online Meeting (pp. 165-168). Hinksey Hill, U.K.: Learned Information.

Judge, W. Q., Fryxell, G. E., \& Dooley, R. S. (2000). The new task of R\&D management: Creating goal-directed communities for innovation. In E. L. Lesser, M. A. Fontaine, \& J. A. Slusher (Eds.), Knowledge and communities (pp. 37-51). Oxford: Butterworth-Heinemann.

Kaufer, D., \& Carley, K. (1993). Communication at a distance: The influence of print on sociocultural organization and change. Hillsdale, NJ: Lawrence Erlbaum.

Keiichi, N., Voss, A., Juhnke, M., \& Kreifelts, T. (1998). Concept index: Capturing emergent community knowledge from documents. Designing collective memories. Proceedings of the 7th Travail Humain Workshop (10 pages). Paris: Le Travail Humain.

Kendall, L. (1999). Recontextualizing "cyberspace": Methodological considerations for on-line research. In S. Jones (Ed.), Doing Internet research: Critical issues and methods for examining the Net (pp. 57-74). London: Sage.

Kingston, J., \& Macintosh, A. (2000). Knowledge management through multiperspective modelling: Representing and distributing organisational memory. Knowledge Based Systems Journal, 13(2/3), 121-131.

Kling, R., \& Elliott, M. (1994). Digital library design for organizational usability. SIGOIS Bulletin, 15(2), 59-70.

Kling, R., \& Lamb, R. (1996). Analyzing alternative visions of electronic publishing and digital libraries. In R. Peek \& G. Newby (Eds.), Scholarly publishing: The electronic frontier (pp. 17-54). Cambridge, MA: MIT Press.

Kling, R., McKim, G., Fortuna, J., \& King, A. (2000). A bit more to IT: Scientific multiple media communication forums as socio-technical interaction networks (working paper). Retrieved November 16, 2000, from the World Wide Web: http://www.slis.indiana.edu/SCIT/a-bit-more-to-it.pdf

Kollock, P. (1999). Economies of online cooperation: Gift and public goods in cyberspace. In M. Smith \& P. Kollock (Eds.), Communities in cyberspace (pp. 220-239). London: Routledge.

Kransdorff, A. (2000). Knowledge management's role in experiential learning. In S. Rock (Ed.), Liberating knowledge (pp. 73-79). London: IBM/CBI.

Kuutti, K. (1996). Activity theory as a potential framework for human-computer interaction research. In B. Nardi (Ed.), Context as consciousness: Activity theory and human-computer interaction (pp. 17-44). Cambridge, MA: MIT Press. 
Lam, A. (2000). Tacit knowledge, organizational learning and societal institutions: An integrated framework. Organization Studies, 21, 487-513.

Lamb, R. (1999). Using intranets: Preliminary results from a socio-technical field study. In R. Sprague (Ed.), Proceedings of the 32nd Annual Hawaii International Conference on System Sciences (CD ROM). Los Alamitos, CA: IEEE.

Landay, J., \& Davis, R. (1999). Making sharing pervasive: Ubiquitous computing for shared note taking. IBM Systems Journal, 38, 531-550.

Latour, B., \& Woolgar, S. (1979). Laboratory life: The social construction of scientific facts. Beverley Hills, CA: Sage.

Lave, J. (1988). Cognition in practice: Mind, mathematics, and culture in everyday life. New York: Cambridge University Press.

Lave, J. (1991). Situated learning in communities of practice. In L. Resnick, J. M. Levine, \& S. D. Teasley (Eds.), Perspectives on socially shared cognition (pp. 63-82). Washington, DC: American Psychological Association.

Lave, J., \& Wenger, E. (1991). Situated learning: Legitimate peripheral participation. Cambridge: Cambridge University Press.

Leonard, D., \& Sensiper, S. (1998). The role of tacit knowledge in group innovation. California Management Review, 40(3), 112-132.

Lesser, E. (2000). Leveraging social capital in organizations. In E. L. Lesser (Ed.), Knowledge and social capital: Foundations and applications (pp. 3-16). Oxford: Butterworth-Heinemann.

Lesser, E. L., \& Prusak, L. (2000). Communities of practice, social capital and organizational knowledge. In E. L. Lesser, M. A. Fontaine, \& J. A. Slusher (Eds.), Knowledge and communities (pp. 123-131). Oxford: ButterworthHeinemann.

Lesser, E. L., Fontaine, M. A., \& Slusher, J. A. (Eds.). (2000). Knowledge and communities. Oxford: Butterworth-Heinemann.

Lewicki, R., \& Bunker, B. (1996). Developing and maintaining trust in working relationships. In R. Kramer \& T. Tyler (Eds.), Trust in organizations (pp. 114-139). London: Sage.

Loos, I. (1999). Intertextual networks in organisations: The use of written and oral business discourse in relation to context. In F. Bargiela-Chiapinni \& C. $R$. Nickerson (Eds.), Writing business: Genres, media and discourses (pp. 315-332). London: Longman.

Lutters, W., \& Ackerman, M. (1997). A collectivity in electronic social space. SIGGROUP Bulletin, 18(1), 41-43.

Lyman, P. (1999). Designing libraries to be learning communities. In S. Criddle, L. Dempsey, \& R. Heseltine (Eds.), Information landscapes for a learning society: Networking and the future of libraries 3 (pp. 75-87). London: Library Association.

Lynch, C. (1999). Civilising the information ecology. In S. Criddle, L. Dempsey, \& R. Heseltine (Eds.), Information landscapes for a learning society: Networking and the future of libraries 3 (pp. 257-267). London: Library Association. 
Macaulay, C. (1999). Inscribing the palimpsest: Information sources in the newsroom. In K. Buckner (Ed.), Esprit i3 workshop on ethnographic studies in real and virtual environments: Inhabited information spaces and connected communities (pp. 42-52). Edinburgh: Queen Margaret College.

Mackay, W. (1999). Is paper safer? The role of paper flight strips in air traffic control. ACM Transactions on Computer-Human Interaction, 6, 316-340.

Maes, P., Guttman, R., \& Moukas, A. (1999). Agents that buy and sell. Communications of the ACM, 42(3), 81-91.

Marsh, S., \& Meech, J. (2000). Trust in design. In G. Szillus \& T. Turner (Eds), CHI '00 extended abstracts (pp. 45-46). New York: ACM Press.

Marshall, C. C., Shipman, F. M., \& McCall, R. (2000). Making large-scale information resources serve communities of practice. In E. L. Lesser, M. A. Fontaine, \& J. A. Slusher (Eds.), Knowledge and communities (pp. 225-247). Oxford: Butterworth-Heinemann.

McVeigh, T. (2000, March 26). Mind virus could give us the shopping bug. Observer, p. 7.

McWilliam, G. (2000). Building stronger brands through online communities. Sloan Management Review, 41(3), 43-54.

Merali, Y. (2000). Self-organising communities. In S. Rock (Ed.), Liberating knowledge (pp. 80-87). London: IBM/CBI.

Millen, D., \& Dray, S. (1999). Information sharing in an online community of journalists. In K. Buckner (Ed.), Esprit i3 workshop on ethnographic studies in real and virtual environments: Inhabited information spaces and connected communities (pp. 53-60). Edinburgh: Queen Margaret College.

Morrison, J. (1997). Organizational memory information systems: Characteristics and development strategies. In J. Nunamaker \& R. Sprague (Eds.), Proceedings of the 13th Annual Hawaii International Conference on System Sciences (pp. 300-309). Los Alamitos, CA: IEEE.

Murphy, L. (2001). Digital documents in organizational communities of practice: A first look. In R. Sprague (Ed.), Proceedings of the 34th Annual Hawaii International Conference on Systems Sciences (CD-ROM). Los Alamitos, CA: IEEE.

Mynatt, E., Adler, A., Ito, M., \& O'Day, V. (1997). Design for network communities. CHI 97 Conference Proceedings on Human Factors in Computing Systems (pp. 210-217). New York: ACM Press.

Nahapiet, J., \& Ghoshal, S. (2000). Social capital, intellectual capital and the organizational advantage. In E. L. Lesser (Ed.), Knowledge and social capital (pp. 119-157). Oxford: Butterworth-Heinemann.

Naper, I. (2001). System features of an inhabited 3D virtual environment supporting multimodality in communication. In R. Sprague (Ed.), Proceedings of the 34th Annual Hawaii International Conference on Systems Sciences (CDROM). Los Alamitos, CA: IEEE.

Nardi, B. (Ed.). (1996). Context and consciousness: Activity theory and humancomputer interaction. Cambridge, MA: MIT Press. 
Nardi, B., \& O'Day, V. (1999). Information ecologies: Using technology with heart. Cambridge, MA: MIT Press.

Newell, S., Scarborough, H., Swan, J., \& Hislop, D. (2000). Intranets and knowledge management: De-centred technologies and the limits of technological discourse. In C. Prichard, R. Hull, M. Chumer, \& H. Willmott (Eds.), Managing knowledge: Critical investigations of work and learning (pp. 88-106). Basingstoke, U.K.: Macmillan.

Nonaka, I. (1991). The knowledge-creating company. Harvard Business Review, $69(6), 14-37$.

Nonaka, I., \& Konno, N. (1998). The concept of "Ba": Building a foundation for knowledge creation. California Management Review, 40(3), 40-54.

Nonaka, I., \& Takeuchi, H. (1995). The knowledge creating company. New York: Oxford University Press.

Nonaka, I., Umemoto, K., \& Sasaki, K. (1998). Three tales of knowledge creating companies. In G. Von Krogh, J. Roos, \& D. Kleine (Eds.), Knowing in firms: Understanding, managing and measuring knowledge (pp. 146-172). London: Sage.

Nonnecke, B., \& Preece, J. (1999). Shedding light on lurkers in online communities. In K. Buckner (Ed.), Esprit i3 workshop on ethnographic studies in real and virtual environments: Inhabited information spaces and connected communities (pp. 123-128). Edinburgh: Queen Margaret College.

Nowak, M., \& Sigmund, K. (2000, 5 May). Shrewd investments. Science, 288, $819-820$.

O'Dell, C., \& Jackson Grayson, C. (1998). If only we knew what we know: Identification and transfer of internal best practices. California Management Review, 40(3), 154-174.

Orlikowski, W. (1993). Learning from Notes: Organizational issues in groupware implementation. The Information Society, 9(3), 237-250.

Orlikowski, W., \& Yates, J. (1994). Genre repertoire: The structuring of communicative practices in organizations. Administrative Science Quarterly, 39, $541-574$.

Orr, J. (1987, June). Narratives at work: Story telling as cooperative diagnostic activity. Field Service Manager, 47-60.

Orr, J. (1990). Sharing knowledge, celebrating identity: Community memory in a service culture. In D. Middleton \& D. Edwards (Eds.), Collective remembering (pp. 168-169). London: Sage.

Pejtersen, A., \& Albrechtsen, H. (2000). Ecological work based classification schemes. In C. Beghtol, L. Howarth, \& N. Williamson (Eds.), Dynamism and stability in knowledge organization. Proceedings of the Sixth International ISKO Conference: Advances in Knowledge Organization (pp. 97-110). Wurzburg: Ergon Verlag.

Perry, M. (1998). Process, representation and taskworld: Distributed cognition and the organisation of information. In T. Wilson \& D. Allen (Eds.), Exploring the contexts of information behaviour: Proceedings of the Second International 
Conference on Research in Information Needs, Seeking and Use in Different Contexts (pp. 552-567). London: Taylor Graham.

Raeithel, A., \& Velichkovsky, B. (1996). Joint attention and co-construction: New ways to foster user-designer collaboration. In B. Nardi (Ed.), Context and consciousness: Activity theory and human-computer interaction (pp. 199-231). Cambridge, MA: MIT Press.

Rasmussen, J., Pejtersen, A., \& Goodstein, L. (1994). Cognitive systems engineering. New York: John Wiley.

Reed, D. (2001) "Making conversation:" Sequential integrity and the local management of interaction on Internet newsgroups. In R. Sprague (Ed.), Proceedings of the 34th Annual Hawaii International Conference on Systems Sciences (CD-ROM). Los Alamitos, CA: IEEE.

Resnick, L., Levine, J. M., \& Teasley, S. D. (1991). Perspectives on socially shared cognition. Washington, DC: American Psychological Association.

Rioux, K. (2000). Sharing information for others on the World Wide Web: A preliminary examination. Proceedings of the 63rd Annual Meeting of the American Society for Information Science, 68-77.

Romano, N., Nunamaker, J., Briggs, R., \& Vogel, D. (1998). Architecture, design and development of an HTML/JavaScript Web-based group support system. Journal of the American Society for Information Science, 49, 649-667.

Ruggles, R. (1998). The state of the notion: Knowledge management in practice. California Management Review, 40(3), 80-89.

Salomon, G. (Ed.). (1993a). Distributed cognitions. New York: Cambridge University Press.

Salomon, G. (1993b). No distribution without individual's cognition: A dynamic interactional view. In G. Salomon (Ed.), Distributed cognitions (pp. 111-138). New York: Cambridge University Press.

Samitt, M. K. (1999). Knowledge management in a corporate environment: An annotated bibliography. Business and Finance Bulletin, 110, 39-50.

Sauvagnac, C., \& Falzon, P. (1998). Memorizing decisions: From the report to organizational knowledge. In P. Marti \& S. Bagnara (Eds.), Designing Collective Memories. Proceedings of the 7 th Travail Humain Workshop (8 pages). Paris: Le Travail Humain.

Sawnhey, M., \& Pirandelli, E. (2000). Communities of creation. California Management Review, 42(4), 24-54.

Sawyer, S., Eschenfelder, K., \& Heckman, R. (2000). Knowledge markets: Cooperation among distributed technical specialists. In T. Srikantaiah \& M. Koenig (Eds.), Knowledge management for the information professional (pp. 181-204). Medford, NJ: Information Today, Inc.

Scheepers, R., \& Damsgaard, J. (1997). Using Internet technology within the organization: A structurationalist analysis of intranets, Proceedings of Group 97, Phoenix Arizona (pp. 9-18). New York: ACM Press.

Schiff, L., Van House, N., \& Butler, M. (1997). Understanding complex information environments: A social analysis of watershed planning. In R. Allen \& E. 
Rasmussen (Eds.), Proceedings of the 2nd ACM International Conference on Digital Libraries (pp. 161-168). New York: ACM Press.

Schlegoff, E. (1991). Conversation analysis and socially shared cognition. In L. Resnick, J. M. Levine, \& S. D. Teasley (Eds.), Perspectives on socially shared cognition (pp. 150-171). Washington, DC: American Psychological Association.

Schön, D. (1983). Reflective practice in the science-based professions. In D. Schön (Ed.), The reflective practitioner (pp. 168-203). New York: Basic Books.

Schultze, U., \& Boland, R. (1997). Hard and soft information genres: An analysis of two Notes databases. In J. Nunamaker \& R. Sprague (Eds.), Proceedings of the 30th Annual Hawaii International Conference on System Sciences (pp. 40-49). Los Alamitos, CA: IEEE.

Snowden, D. (1998). A framework for creating an acceptable programme. In S. Rock (Ed.), Knowledge management: A real business guide (pp. 7-17). London: $\mathrm{CBI} / \mathrm{IBM}$.

Snowden, D. (2000). Liberating knowledge. In S. Rock (Ed.), Liberating knowledge (pp. 6-19). London: IBM/CBI.

Soergel, D. (1998). Design of an integrated information structure interface. A unified framework for indexing and searching in database, expert, information retrieval and hypermedia systems. (Unpublished internal paper): College of Library and Information Services, University of Maryland.

Soergel, D. (1999). The rise of ontologies or the re-invention of classification. Journal of the American Society for Information Science, 50, 1119-1120.

Solomon, P. (1998). Information mosaics: Patterns of action that structure. In T. Wilson \& D. Allen (Eds.), Exploring the contexts of information behaviour: Proceedings of the Second International Conference on Research in Information Needs, Seeking and Use in Different Contexts (pp. 150-175). London: Taylor Graham.

Sonnenwald, D. (1998). Perspectives of human information behaviour: Contexts, situations, social networks and information horizons. In T. Wilson \& D. Allen (Eds.), Exploring the contexts of information behaviour: Proceedings of the Second International Conference on Research in Information Needs, Seeking and Use in Different Contexts (pp. 176-190). London: Taylor Graham.

Star, S. (1995). The politics of formal representations: Wizards, gurus and organizational complexity. In S. Star (Ed.), Ecologies of knowledge: Work and politics in science and technology. Albany, NY: State University of New York Press.

Star, S., \& Griesemer, J. (1989). Institutional ecology, "translations" and boundary objects: Amateurs and professionals in Berkeley's Museum of Vertebrate Zoology. Social Studies of Science, 19, 387-420.

Star, S., \& Ruhlehder, K. (1994). Steps towards an ecology of infrastructure: Complex problems in design and access for large-scale collaborative systems. In R. Furuta \& C. Neuwirth (Eds.), CSCW' 94: Proceedings of the Conference on Computer-Supported Cooperative Work (pp. 253-264). New York: ACM Press. 
Stein, E. (1995). Organizational memory: Review of concepts and recommendations for management. International Journal of Information Management, 15(2), 17-32.

Stinchcombe, A. (1965). Social structure and environment. In J. March (Ed.), The handbook of organizations (pp. 142-193). Berkeley, CA: University of California Press.

Storck, J., \& Hill, P. (2000). Knowledge diffusion through "strategic communities." Sloan Management Review, 41(2), 63-74.

Suchman, L. (1986). Plans and situated actions: The problem of human-machine communication. Cambridge: Cambridge University Press.

Suchman, L. (2000). Organizing alignment: A case of bridge-building. Organization, 7, 311-327.

Suchman, L., \& Trigg, R. (1993). Artificial intelligence as craftwork. In S. Chaiklin \& J. Lave (Eds.), Understanding practice: Perspectives on activity and context (pp. 144-178). Cambridge: Cambridge University Press.

Swales, J. (1990). Genre analysis: English in academic and research setting. Cambridge: Cambridge University Press.

Swan, J., \& Scarbrough, H. (2001). Knowledge, purpose, and process: Linking knowledge management and innovation. In R. Sprague (Ed.), Proceedings of the 34th Annual Hawaii International Conference on Systems Sciences (CDROM). Los Alamitos, CA: IEEE.

Tannen, D. (1995). What's in a frame? Surface evidence for underlying expectations. In G. Psathas (Ed.), Conversation analysis: The study of talk-in-interaction (pp.138-181). Thousand Oaks, CA: Sage.

Teigland, R. (2000). Communities of practice at an Internet firm: Netovation vs. on-time performance. In E. L. Lesser, M. A. Fontaine, \& J. A. Slusher (Eds.), Knowledge and communities (pp. 151-178). Oxford: Butterworth-Heinemann.

Tsoukas, H. (1996). The firm as a distributed knowledge system: A constructionist approach. Strategic Management Journal 17(special issue), 11-25.

Turkle, S. (1996). Life on the screen. Cambridge, MA: MIT Press.

Twidale, M., \& Nichols, D. (1996). Collaborative browsing and visualisation of the search process. Aslib Proceedings, 48(7/8), 177-182.

Uschold, M., King, M., Moralee, S., \& Zorgios, V. (1999). The enterprise ontology. Knowledge Engineering Review, 13(1), 31-89.

Vakkari, P., Savolainen, R., \& Dervin, B. (1997). Information seeking in context. London: Taylor Graham.

van der Spek, R., \& Kingma, J. (2000). Achieving successful knowledge management initiatives. In S. Rock (Ed.), Liberating knowledge (pp. 20-30). London: IBM/CBI.

Van House, N. (in press). Digital libraries and collaborative knowledge construction. In A. Bishop, B. B. Buttenfield, \& N. Van House (Eds). Digital library use: Social practice in design and evaluation. Cambridge, MA: MIT Press.

Vickery, B. (1997). Ontologies. Journal of Information Science, 23, 277-286.

von Krogh, G. (1998). Care in knowledge creation. California Management Review, 40(3), 133-153. 
von Krogh, G., Ichijo, K., \& Nonaka, I. (2000). Enabling knowledge creation: How to unlock the mystery of tacit knowledge and release the power of innovation. Oxford: Oxford University Press.

Wedekind, C., \& Milinski, M. (2000). Cooperation through image scoring in humans. Science, 288, 850-852.

Weick, K. (1995). The substance of sense making. In K. Weick (Ed.), Sensemaking in organizations (pp. 106-131). Thousand Oaks, CA: Sage.

Weick, K. (1996). The non-traditional quality of organizational learning. In M. D. Cohen \& L. S. Sproull (Eds.), Organizational learning (pp. 163-174). London: Sage.

Weick, K., \& Roberts, K. (1993). Collective mind in organizations: Heedful interrelating on flight decks. Administrative Science Quarterly, 38, 357-381.

Wellman, B., \& Gulia, M. (1999). Virtual communities as communities: Net surfers don't ride alone. In M. Smith \& P. Kollock (Eds.), Communities in cyberspace (pp. 167-194). London: Routledge.

Wenger, E. (1998). Communities of practice: Learning, meaning and identity. New York: Cambridge University Press.

Wenger, E. (2000a). Communities of practice: The key to knowledge strategy. In E. L. Lesser, M. A. Fontaine, \& J. A. Slusher (Eds.), Knowledge and communities (pp. 3-20). Oxford: Butterworth-Heinemann.

Wenger, E. (2000b). Communities of practices and social learning systems. Organization, $7(2), 225-246$.

Wenger, E., \& Snyder, W. (2000). Communities of practice: The organizational frontier. Harvard Business Review, 78(1), 139-145.

Wexelblat, A. (1999). History-based tools for navigation. In R. Sprague (Ed.), Proceedings of the 32nd Annual Hawaii International Conference on System Sciences (CD ROM). Los Alamitos, CA: IEEE.

Wexelblat, A., \& Maes, P. (1999). Footprints: History-rich tools for information foraging. Proceedings of the CHI '99 Conference on Human Factors in Computing Systems: The CHI is the limit (pp. 270-277). New York: ACM Press.

Wilson, T., \& Allen, D. (Eds.). (1998). Exploring the contexts of information behaviour: Proceedings of the Second International Conference on Research in Information Needs, Seeking and Use in Different Contexts. London: Taylor Graham.

Wolf, C. (1997). Transient coooperating communities. SIGGROUP Bulletin, 18(1), 47-49.

Wright, P., Pocock, S., \& Fields, B. (1988). The prescription and practice of work on the flight deck. In P. Wright \& B. Fields (Eds.), Understanding work and designing artefacts (seven pages). York: Department of Computer Science, University of York.

Yanow, D. (2000). Seeing organizational learning: A "cultural" view. Organization, 7, 247-268. 
Yates, J., \& Orlikowski, W. (1992). Genres of organizational communication: A structurational approach to studying communication and media. Academy of Management Review, 17(2), 299-326.

Yates, J., Orlikowski, W., \& Rennecker, J. (1997). Collaborative genres for collaboration: Genre systems in digital media. In J. Nunamaker \& R. Sprague (Eds.), Proceedings of the 30th Annual Hawaii International Conference on System Sciences (pp. 50-59). Los Alamitos, CA: IEEE.

Yates, S., \& Sumner, T. (1997). Digital genres and the new burden of fixity. In J. Nunamaker \& R. Sprague (Eds.), Proceedings of the 30th Annual Hawaii International Conference on System Science. (pp. 3-12). Los Alamitos, CA: IEEE. 